\title{
How has Tooth Manipulation been Conducted for Dental Pulp Stem Cells Isolation? A Scoping Review
}

\author{
${ }^{1}$ Camila P Ferrúa, ${ }^{2}$ Cainá C do Amaral, ${ }^{3}$ Roberta Giorgi, ${ }^{4}$ Tiago Garcia, ${ }^{5}$ Fernanda Nedel
}

\begin{abstract}
The aim of this study was to realize a scoping review the literature to verify how tooth manipulation for dental pulp stem cells (DPSCs) isolation has been conducted and if a standard tooth, preparation protocol for DPSCs isolation exists. The electronic search was conducted without initial date restriction up to and including April 2014 in PubMed, Scopus, Scielo, and ISI Web of Knowledge databases to identify studies that described the methodology used for DPSCs isolation. Two hundred and twenty-two articles were included and the information analysis was performed concerning dental manipulation and pulp tissue processing.
\end{abstract}

Furthermore, the quality of included studies was evaluated through the assessment of the risk of bias. This scoping review established a platform for dental manipulation protocols for DPSCs isolation purposes. Over the past years, many studies have been conducted using DPSCs. However, there is a clear lack of standardization in tooth manipulation before DPSCs isolation. Currently, given a large number of variables in cell isolation techniques and all possible consequences in the in vitro behavior of cells, it is important to reinforce the importance of standard protocols to obtain a uniform cell culture.

Keywords: Dental pulp, Dental pulp stem cell, Manipulation, Scoping review, Stem cell.

How to cite this article: Ferrúa CP, Amaral CC do, Giorgi R, Garcia T, Nedel F. How has Tooth Manipulation been Conducted for Dental Pulp Stem Cells Isolation? A Scoping Review. Int J Experiment Dent Sci 2018;7(2):98-135.

Source of support: Nil

Conflict of interest: None

\section{INTRODUCTION}

Mesenchymal stem cells (MSCs) have been considered a promising treatment alternative for illnesses such as type 1 diabetes $^{1}$ and heart disease, ${ }^{2}$ among others. Advances

\footnotetext{
${ }^{1-4}$ Student, ${ }^{5}$ Professor

${ }^{1-5}$ Department of Postgraduate Program in Health and Behavior, Catholic University of Pelotas, Pelotas, Rio Grande do Sul, Brazil

Corresponding Author: Fernanda Nedel, Professor, Department of Postgraduate Program in Health and Behavior, Catholic University of Pelotas, Pelotas, Rio Grande do Sul, Brazil, e-mail: fernanda.nedel@gmail.com
}

in the treatment of these diseases are closely associated with the growing number of stem cell research; however, most studies are developed in animal models, suggesting that more research is needed to translate results to human applications. ${ }^{3}$ For this, a cell source easily obtainable, with rapid in vitro expansion and high proliferative rates is mandatory. Among available options with such characteristics are the dental pulp stem cells (DPSCs). ${ }^{4}$

DPSCs are found in small quantities in the human dental pulp. ${ }^{1,5}$ Therefore, the simulation of the cellular microenvironment must be the best possible to achieve a sufficient cell proliferation rate and quality for in vitro or in vivo purposes. ${ }^{6}$ However, teeth manipulation and pulp tissue processing for cell isolation is a complex task and can be determinant in the success of stem cell isolation.?

Although DPSCs have been widely used in studies with clinical applications, the literature is scarce in relation to tooth preparation before DPSCs isolation. Thus, the aim of this study was to realize a scoping review to verify how tooth manipulation for DPSCs isolation has been conducted and if a standard tooth preparation protocol exists. To the best of our knowledge, this is the first scoping review evaluating tooth manipulation for DPSCs isolation.

\section{MATERIALS AND METHODS}

\section{Study Questions}

How tooth manipulation for DPSCs isolation has been conducted?

Is there a standardized protocol for tooth manipulation to isolate DPSCs?

\section{Inclusion and Exclusion Criteria}

To be included, the study had to describe stem cell isolation from human dental pulp of permanent teeth. Exclusion criteria were studies using cells from a nonhuman source, stem cells from sources other than the dental pulp, human cells but not stem cells, SHEDs, and studies in which the tooth manipulation and isolation technique were not described. Literature reviews, congress abstracts, patents, book section, hypothesis articles, editorial, letters to the editor, news, protocols, interview, articles which are not written in English and that were not fully available even after attempting to contact the authors were also excluded. Articles were not excluded due to more than one exclusion criterion. 


\section{Search Strategy}

The electronic search was conducted without initial date restriction up to and including April 2014 in PubMed, Scopus, Scielo, and ISI Web of Knowledge databases to identify studies that described the methodology used for DPSCs isolation. An initial search was conducted using the following terms: "[(dental pulp stem cell (MeSH)]"; "[dental pulp (MeSH)]" and "[stem cell (MeSH)]"; "["dental pulp stem cell" (MeSH)]". No language and date restrictions were applied in the search.

All references were managed in EndNote X7 software (Thomson Reuters, New York, NY, US). Initially, duplicate references were excluded. Titles, abstracts, and methodologies were screened based on the inclusion and exclusion criteria by two reviewers independently (CPF and CCdoA). Lists were compared, and in case of disagreement, a consensus was reached by discussion. When a consensus was not achieved, a third reviewer decided if the article should be included (FN). This scoping review followed the PRISMA statements ${ }^{8}$ with some adjustments (Fig. 1).

\section{Data Extraction}

After screening, the following data were collected from articles: name of authors, year of publication, donor's age, donor's gender, tooth type, time and tooth storage methods between the extraction and DPSCs isolation, tooth surface cleaning methods, location and methods of dental section, and methods used to remove the pulp from the dental chamber. Data were extracted and tabulated independently by two reviewers (CPF and RGS) to be submitted to a descriptive analysis. Cases of disagreement were discussed until a consensus was reached. When a consensus was not obtained, a third reviewer participated in the discussion (FN).

\section{Assessment of Risk of Bias}

Risk of bias was evaluated according to the following parameters for study quality assessment (a) donor's age, (b) donor's gender, (c) tooth type, (d) tooth storage methods, (e) tooth storage time, (f) dental surface cleaning (g) dental section methods (h) dental section location and (h) pulp removal methods. A parameter was given a "Y" (yes) if it was described in the study, if it was mentioned but not specifically, it was marked with a " $U$ " (unclear); and finally if the parameter was not described, it was given an "N" (no). After the evaluation, the data were imported into Review Manager 5.3 for analysis and graph generation. Studies withup to $30 \%$ of " $Y$ " had a high risk of bias, above $30 \%$ and lower than $65 \%$ had a medium risk, and above $65 \%$ low risk of bias.

\section{RESULTS}

\section{Descriptive Analysis}

The electronic search yield 3.126 articles. From those, 1.539 were duplicated and removed. A total of 1.587 articles were included by title, abstract, and methodology screening. From those, 222 were included for full-text analysis (Fig. 1).

Most of the studies were published in 2011 and 2013 (Supplementary material 1). Figure 2 shows that tooth donorsare predominantly males with an age range from 17.5-30.6 years.

Of the studies included in this review, 84\% described the type of tooth used for DPSCs isolation. The second most frequently mentioned item was the donor's age $(67.6 \%)$. However, the tooth storage time and method were the most neglected ones, described in $11.7 \%$ and $15 \%$, respectively (Table 1 ).

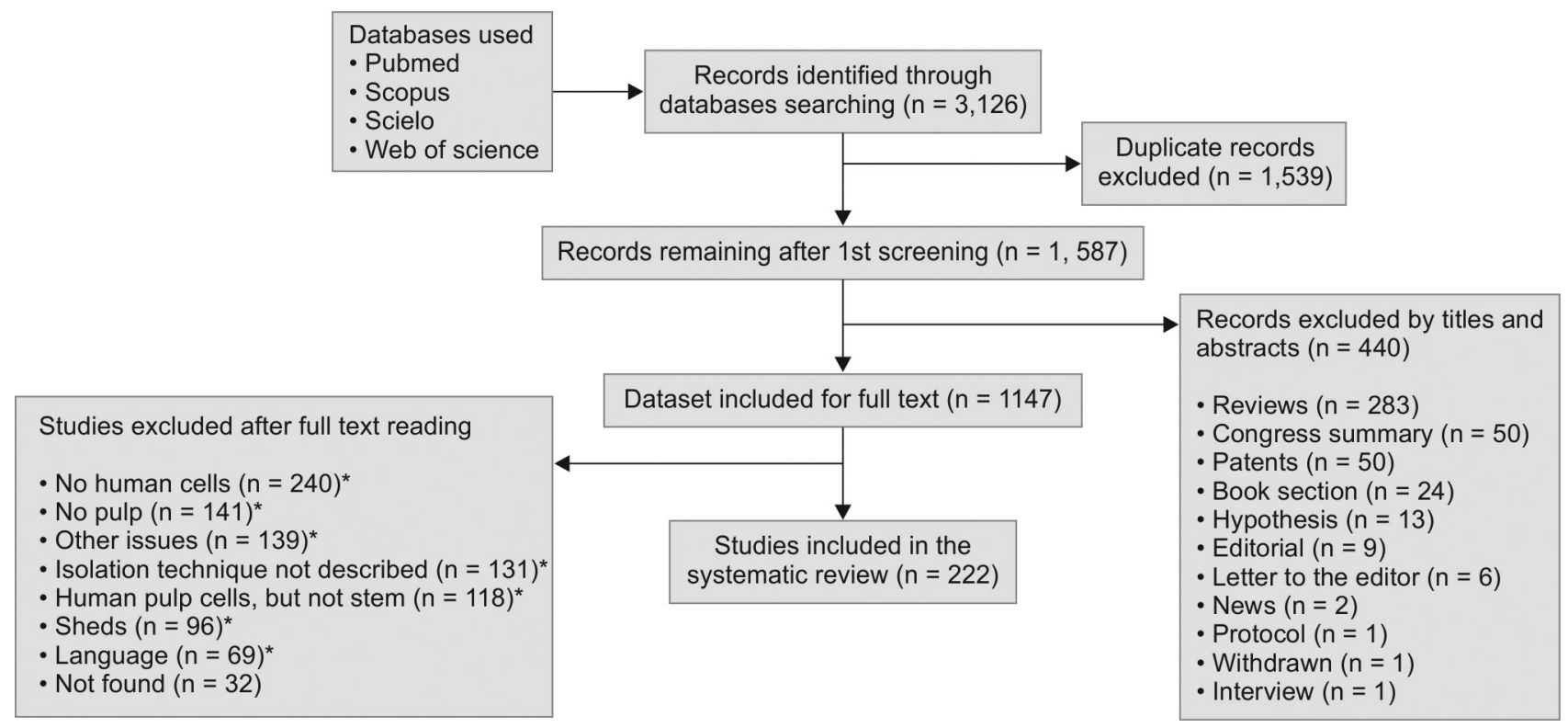

Fig. 1: Flowchart with the studies selection process for inclusion in the systematic review (Exclusion reasons: a study could fulfill more than one criteria) 


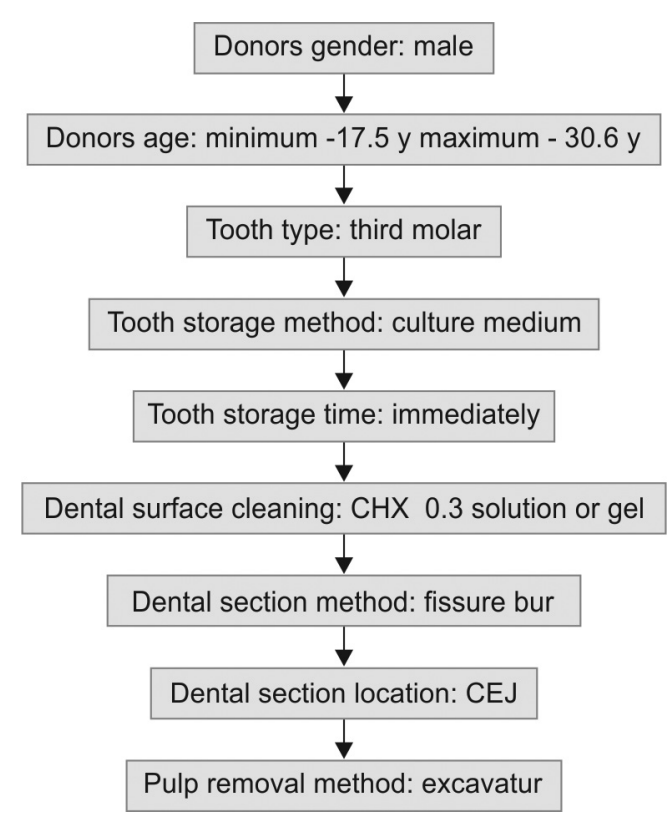

Fig. 2: Flowchart with the most commonly used methods to manipulate tooth prior to DPSCs isolation

Table 1: Distribution according to the presence or absence of important aspects of tooth preparation prior to DPSCs isolation

\begin{tabular}{lllll}
\hline & Yes & \multicolumn{3}{c}{ No } \\
& $N$ & $\%$ & $N$ & $\%$ \\
\hline Tooth type & 187 & 84.2 & 35 & 15.8 \\
Donors age & 150 & 67.6 & 72 & 32.4 \\
Donors gender & 35 & 15.8 & 187 & 84.2 \\
Tooth storage methods & 34 & 15.3 & 188 & 84.7 \\
Tooth storage time & 26 & 11.7 & 196 & 88.3 \\
Dental surface cleaning & 85 & 38.3 & 137 & 61.7 \\
Dental section method & 84 & 37.8 & 138 & 62.2 \\
Dental section location & 42 & 18.9 & 180 & 81.1 \\
Pulp removal methods & 54 & 24.3 & 168 & 75.7 \\
\hline
\end{tabular}

Concerning the type of teeth used for DPSCs isolation, data shows that the third molar is the most commonly used, at $77.6 \%$ or even higher since $9.2 \%$ reported just molars without specifying whichone-first, second or third. The second most commonly used teeth are the premolars (10.7\%). Supernumerary and incisors teeth represent $2.6 \%$, and the canine was not mentioned in the studies (Table 2).

In relation to the storage method used to transport the newly extracted teeth to the site of DPSCs isolation, seven different types of solutions were cited. The most common was the same medium used subsequently for DPSCs culture (44\% of the studies), followed by HBBS (20.6\%). Considering the time spent between the extraction and isolation, the majority of authors $(55.6 \%)$ conducted the isolation of DPSCs immediately after extraction and over 92\% within 24 hours (Table 3 ).

Thirty-eight percent of the articles reported cleaningthe tooth surface before sectioning the dental element to access the pulp chamber (Table 1). Thirteen cleaning solutions were mentioned, used alone or in combination with each other. PBS and CHX were the most cited solutions, each one used in $14.7 \%$ of the studies. CHX was
Table 2: Distribution according to the types of teeth used to isolate DPCSs.

\begin{tabular}{lll}
\hline & $N$ & $\%$ \\
\hline Supernumerary & 2 & 1.0 \\
\hline Incisor & & \\
Incisor (not described the type) & 1 & 0.5 \\
Left upper central incisor - traumatized & 1 & 0.5 \\
Left upper lateral incisor - traumatized & 1 & 0.5 \\
Incisor total & 3 & 1.5 \\
Premolar & & \\
Premolar (not described the type) & 18 & 9.2 \\
First premolar & 2 & 1.0 \\
Lower premolar & 1 & 0.5 \\
Premolar total & 21 & 10.7 \\
\hline Molar & & \\
Molar (not described the type) & 18 & $9.2 \%$ \\
\hline Third molar & & \\
Third molar (not described the type) & 88 & 44.9 \\
Impacted third molar & 57 & 29.1 \\
Upper third molar & 3 & 1.5 \\
Mandibular third molar & 1 & 0.5 \\
Non-erupted third molar & 1 & 0.5 \\
Semi-erupted third molar & 1 & 0.5 \\
Semi-impacted third molar & 1 & 0.5 \\
Third molar total & 152 & 77.6 \\
\hline Total & 196 & 100.0 \\
\hline & & \\
\hline
\end{tabular}

Table 3: A) Distribution according to the storage solution used to transport the newly extracted teeth to the site of DPSCs isolation. Abbreviations: Hank's buffered salt solution - HBBS; phosphate buffered saline - PBS; Dulbecco's phosphate buffered saline DPBS; Fetal bovine serum - FBS. B) Distribution according to the tooth storage time between the extraction and DPSCs isolation

\begin{tabular}{lll}
\hline A: Storage solution to transport teeth & & \\
\hline & $N$ & $\%$ \\
\hline Culture medium & 15 & 44.1 \\
HBBS & 7 & 20.6 \\
PBS & 4 & 11.8 \\
DPBS & 2 & 5.9 \\
Saline solution & 2 & 5.9 \\
Freezing medium & 1 & 2.9 \\
FBS & 1 & 2.9 \\
Stored (not described) & 2 & 5.9 \\
\hline Total & 34 & 100.0 \\
\hline B: Tooth storage time & & \\
\hline & $N$ & $\%$ \\
\hline Immediately & 15 & 55.6 \\
Within 2 h & 6 & 22.2 \\
Within 24 h & 4 & 14.8 \\
6 to $48 \mathrm{~h}$ & 1 & 3.70 \\
$72 \mathrm{~h}$ & 1 & 3.70 \\
\hline Total & 27 & 100.0 \\
\hline
\end{tabular}

used in concentrations of 0.2 and $0.3 \%$ as a solution or gel (Table 4).

In the normal procedure, after cleaning, the teeth are sectioned so that the pulp chamber and the pulp tissue can be access. However, only $37.8 \%$ of the papers reported the sectioning method (Table 1). The most used tools 
Table 4: Distribution according to the tooth surface cleaning method. Abbreviations: clorhexidina - CHX; phosphate buffered saline - PBS; Dulbecco's Phosphate-Buffered Saline - DPBS; povidone-iodine - PVP-I; Hank's Balanced Salt Solution - HBSS.

\begin{tabular}{lll}
\hline & $\mathrm{N}$ & $\%$ \\
\hline $\mathrm{CHX}$ & 3 & 2.6 \\
$0,2 \%$ & 1 & 0.9 \\
$0,2 \%$ solution & 3 & 2.6 \\
$0.3 \%$ & 7 & 6.0 \\
$0,3 \%$ solution & 7 & 6.0 \\
$0,3 \%$ gel & 2 & 1,69 \\
Not described the type & 1 & 0.9 \\
Solution & 17 & 14.7 \\
CHX total & 17 & 14.7 \\
PBS & 15 & 12.9 \\
Professional hygiene & 9 & 7.8 \\
DPBS & 9 & 7.8 \\
Ethanol & 8 & 6.9 \\
PVP-I & 4 & 3.5 \\
Physiological solution & 3 & 2.6 \\
Destilled water & 2 & 1.7 \\
Sodium thiosulfate & 1 & 0.9 \\
Sterile surgical blade & 1 & 0.9 \\
HBSS & 1 & 0.9 \\
Dental burs & 1 & 0.9 \\
Dental scaler & 28 & 24.1 \\
Not described & 116 & 100.0 \\
\hline Total & & \\
\hline
\end{tabular}

described were the fissure bur, forceps, and diamond discs, representing $24.7,18.3$, and $11.8 \%$, respectively (Supplementary material 2).

Few studies indicated at which level the teeth were sectioned, of that $88.1 \%$ chose the cementum-enamel junction (CEJ) (Supplementary material 3).

More than $75 \%$ of the articles did not mention the methods used to remove the pulp tissue from inside the dental chamber (Table 1). Eight different instruments were used to remove the pulp tissue, the most common being the excavator, used in $59.7 \%$ of the studies. The second most used instrument was the forceps $(11.7 \%$ of the studies, Supplementary material 4).

\section{Risk of Bias}

Of the 222 included studies, age and tooth type showed a low risk of bias $(>65 \%)$. Dental surface cleaning and section methods showed the medium risk of bias (above $30 \%$ and lower than $65 \%$ ). Donor's gender, tooth storage methods, tooth storage time, section site and pulp removal methods presented a high risk of bias $(<30 \%)$ (Supplementary material).

\section{DISCUSSION}

This scoping review demonstrates that DPSCs isolation has been reported since 2000. In the first five years following the discovery of DPSCs, only five articles were published. The number of publications increased in 2006 (5 publications) and continued to increase in the following years reaching its peak in 2013 (Fig. 3). Although great knowledge in DPSCs biology and its applications has been produced during these years, this scoping review shows the lack of standardization towards dental preparation before DPSCs isolation. This is the first time that the vast literature regarding tooth manipulation for DPSCs isolation has been summarized in a rigorous and replicable manner (Fig. 2).

The most commonly used teeth to obtain DPSCs were the third molars. According to Gronthos et al. ${ }^{4}$ DPSCs derived from molars have a greater degree of cell proliferation in vitro, when compared with bone marrow stem cells (BMSCs), and this behavior is attributed to differences in the development stage of each organ ${ }^{4}$. In addition, third molars are easily accessible and commonly indicated for extraction for orthodontic reasons. ${ }^{9}$

Most articles neglected the description of tooth donors'gender $(84 \%)$, and when described, males were the most prevalent donors (55.9\%) (Table 1). Also, 67.6\% of the articles mentioned the donor's age (Supplementary material), with a range of $17.5-30.6$ years. It has been reported that the final development of the lower and upper third molars occurs at the age of 21.6 and 22.3

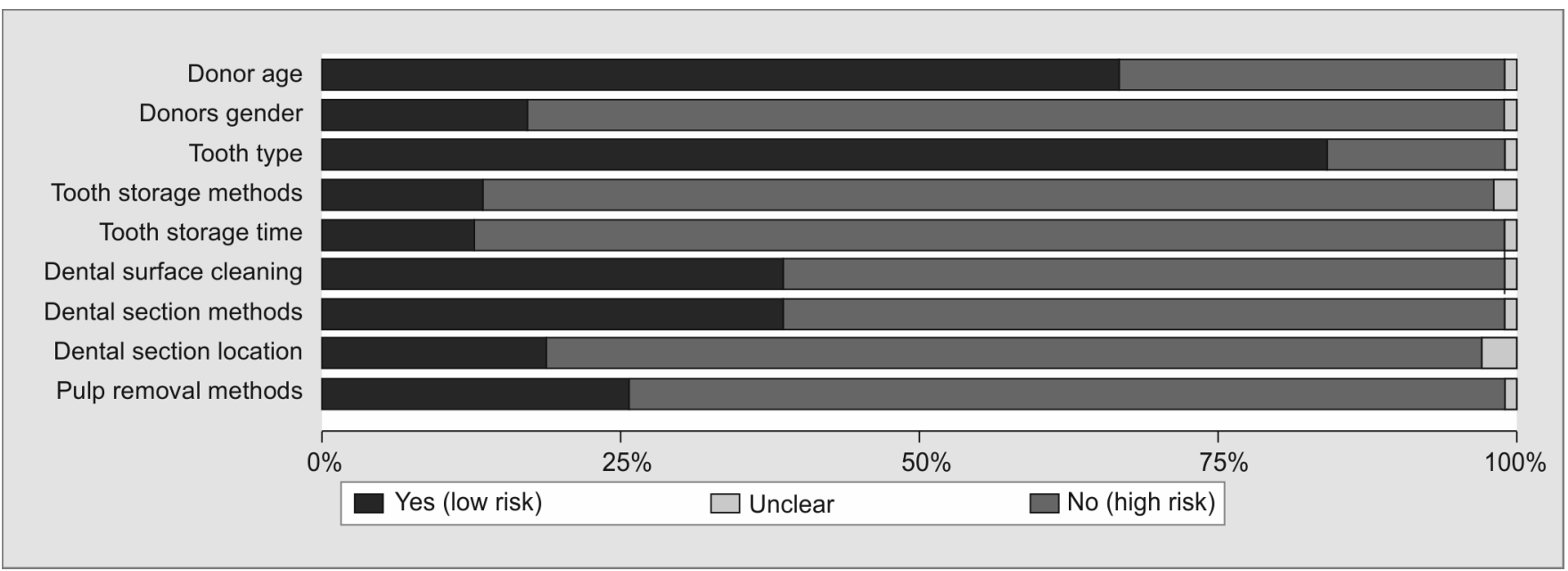

Fig. 3: Risk of bias considering aspects reported in the material and method section 
respectively, in women. In men, the lower and upper third molar complete their development at 21.8 and 22.4 years. ${ }^{10}$ Age-related issues could decrease cell number or function leading to tissue deterioration. ${ }^{11}$ It has been suggested that stem cells from the marrow of younger individuals could have a greater pool size than from older people. The difference is related to the changes in the skeletal dynamics from a modeling mode of skeletal growth and consolidation to a remodeling dynamic of the adult skeleton. ${ }^{12}$ The same occurs with DPSCs, in which the most indicated time for stem cell isolation is during teeth's developmental period, as stem cells are still in growth and consolidation phases, rather than in the remodeling phase.

Often, teeth extraction and dental pulp tissue processing occur in different locations and thus the time and conditions in which teeth are transported to one place to the other are important factors. ${ }^{13,14}$ However, our results indicated that most studies neglected these aspects (Table 1). Even though the need for teeth conditioning is evident. ${ }^{14}$ our results show a high risk of bias for this variable (Fig. 1). The most commonly used media were the same medium used subsequently for DPSCs culture (44.1\%), Hank's balanced salt solution (20.7\%), and PBS (11.7\%).

This review showed that over $88.3 \%$ of the studies did not report teeth storage time (Table 1). Among the studies that reported this factor, $92.6 \%$ initiated cell dissociation within 24 hours after tooth extraction. The literature suggests that teeth maintained in the cell culture medium, PBS or hypo-thermosol (HTS) can conserve DPSCs viability for up to 120 hours, thus contradicting the hypothesis that DPSCs are viable only when isolated within 48 hours after dental extraction. ${ }^{14}$

Another important issue considering teeth processing before DPSCs isolation is the cleaning procedure of the dental surface. Our review showed that nearly $62 \%$ of all studies did not mention the process used for cleaning the tooth surface before the dental section (Table 1). However, this procedure might be critical forthe prevention of cell culture contamination, since more than 700 bacterial species or phylotypes, ${ }^{15}$ mycoplasmas, ${ }^{16}$ and a wide range of fungi ${ }^{17}$ are detected in the oral cavity. The authors who reported this step mainly used substances such as chlorhexidine( $15 \%$ of the total studies). Chlorhexidine has been shown to present antibacterial and antifungal properties, ${ }^{18}$ which justifies its use for surface cleaning before dental section. Chlorhexidinehas bactericidal activity at high concentrations $(>0.12 \%)$ and bacteriostaticactivity at low concentrations $(0.02-0.06 \%) .{ }^{19}$ This could explain why $3.5 \%$ of the authors opted to disinfect the teeth surface with chlorhexidineat $0.2 \%$, while $8.6 \%$ used $0.3 \%$ chlorhexidine. Another group of researchers (2.6\%) used mechanical tools to clean the surface of teeth such as dental burs, a dental scaler, and a sterile surgical blade. Some authors (12.9\%) suggested professional oral prophylaxis before tooth extraction.

As pioneers in DPSCs isolation, Gronthos et al. ${ }^{4}$ provided the basis for many researchers. In agreement to their methodology, $88.1 \%$ of the included studies sectioned the tooth at the cementum-enamel junction, and $24.7 \%$ used dental fissure burs. To perform this step, a high-speed handpiece coupled to a dental unit is used. However, this equipment is often unavailable in most laboratories and therefore it is commonly performed in the clinic, jeopardizing the sterile environment needed to prevent contamination of the pulp tissue, and consequently the cell culture. In addition, the literature suggests that thermal damage should be avoided since a $5.5^{\circ} \mathrm{C}$ increase in intrapulpal temperature can cause irreversible damage to the pulp tissue. ${ }^{20}$ Subsequently, once the pulp chamber has been accessed, the next step is to remove the pulp tissue. Of all the articles included in this review, 75.7\% did not mention this step. According to our findings, the use of excavators is the choice of approximately $60 \%$ of authors who mention the method used for dental pulp tissue removal.

After collecting the dental pulp, DPSCs can be isolated using two main techniques: explant ${ }^{21-23}$ and enzymatic. $^{22,23}$ The association of the enzymatic technique and the use of mechanical devices to intensify cell dissociation is also frequently used. ${ }^{24}$

This scoping review clearly shows the lack of information provided in articles, since a high risk of bias was found in almost all variables evaluated, with exception to donor's age (67.6\%) and tooth type (84.2\%). We propose that information such as donor's age, type of tooth, storage medium, storage time, tooth surface cleaning method, dental section method, tooth section site, and method for removing the pulp tissue from the chamber should be standardized and provided in all original articles, so that protocols could be well established. Based on the frequency that each step of DPSCs isolation was reported in our scoping review, we developed a platform (Fig. 2). However, it is important to highlight that this platform is based on frequency analysis and not in the effectiveness each step. We recognize that ideally the outcomes of the articles should be assessed instead of the frequency of the methods used.

Nonetheless, negative results are usually not published, and if outcomes were to be considered, they could lead to a great risk of bias. In addition, most studies included in this scoping review were not strictly methodological (evaluating only tooth manipulation) andassessed secondary outcomes. We can speculate, however, that if DPSCs isolation was described in the methodology section of studies evaluating secondary variables, the tooth manipulation method was successful. Therefore, we believe that the frequency of methods would be the most accurate data to evaluate. 


\section{CONCLUSION}

Over the past 15 years, many studies have been conducted using DPSCs. However, there is a clear lack of standardization in tooth manipulation before DPSCs isolation. Thus, given a large number of variables in cell isolation techniques and its consequences in the in vitro behavior of cells, it is important to reinforce the need for standard protocols to obtain a uniform cell culture.

\section{CLINICAL SIGNIFICANCE}

Tooth manipulation for DPSCs isolation is a complex task, dependent on aspects such as time and tooth storage methods between the extraction and DPSCs isolation, tooth surface cleaning methods, location and methods of the dental section, and methods used to remove the pulp from the dental chamber, which determine the success of stem cell isolation. The adequate process of cell isolation seems to be fundamental for the use of these cells as therapeutic tools in tissue engineering, cell therapy, and other health areas.

\section{REFERENCES}

1. Liu Y, Cao DL, Guo LB, et al. Amniotic stem cell transplantation therapy for type 1 diabetes: a case report. The Journal of international medical research. 2013;41(4):1370-1377.

2. Padda J, Sequiera GL, Sareen N, et al. Stem cell therapy for cardiac regeneration: hits and misses. Canadian Journal of Physiology and Pharmacology 2015;93(10):835-841.

3. de Souza PV, Alves FB, Costa Ayub CL, et al. Human immature dental pulp stem cells (hIDPSCs), their application to cell therapy and bioengineering: an analysis by systematic revision of the last decade of literature. Anatomical Record 2013;296(12):1923-1928.

4. Gronthos S, Mankani M, Brahim J, et al. Postnatal human dental pulp stem cells (DPSCs) in vitro and in vivo. Proc Natl Acad Sci USA 2000;97(25):13625-30.

5. Fischbach GD, Fischbach RL. Stem cells: science, policy, and ethics. The Journal of Clinical Investigation 2004;114(10):13641370.

6. Caplan AI. Why are MSCs therapeutic? New data: new insight. The Journal of Pathology 2009;217(2):318-324.

7. Kerkis I, Caplan AI. Stem cells in dental pulp of deciduous teeth. Tissue engineering Part B, Reviews 2012;18(2):129-138.

8. Moher D, Liberati A, Tetzlaff J, Altman DG, Group P. Preferred reporting items for systematic reviews and meta-analyses: the PRISMA statement. BMJ 2009;151:264-269.

9. Kellner M, Steindorff MM, Strempel JF, et al. Differences of isolated dental stem cells dependent on donor age and consequences for autologous tooth replacement. Archives of Oral Biology 2014;59(6):559-567.
10. Jafari A, Mohebbi S, Khami M, et al. Radiographic evaluation of third molar development in 5- to 25 year olds in tehran, iran. Journal of Dentistry 2012;9(2):107-115.

11. Hartwig FP, Nedel F, Collares TV, et al. Telomeres and tissue engineering: the potential roles of TERT in VEGF-mediated angiogenesis. Stem Cell Reviews 2012;8(4):1275-1281.

12. Bellantuono I, Aldahmash A, Kassem M. Aging of marrow stromal (skeletal) stem cells and their contribution to age-related bone loss. Biochimica et biophysica acta. 2009;1792(4):364-370.

13. Ducret M, Fabre H, Degoul O, et al. Manufacturing of dental pulp cell-based products from human third molars: current strategies and future investigations. Frontiers in Physiology 2015;6:213

14. Perry BC, Zhou D, Wu X, et al. Colletion, cryopreservation, and characterization of human dental pulp-derived mesenchymal stem cells for banking and clinical use. Tissue Eng Part C Methods 2008;14(2):149-156.

15. Aas JA, Paster BJ, Stokes LN, et al. Defining the normal bacterial flora of the oral cavity.Journal of Clinical Microbiology 2005;43(11):5721-5732.

16. Kim BC, Kim SY, Kwon YD, et al. Mycoplasma detection and elimination are necessary for the application of stem cell from human dental apical papilla to tissue engineering and regenerative medicine. Biomaterials research. 2015;19:19:6.

17. $\mathrm{Xu} \mathrm{H}$, Dongari-Bagtzoglou A. Shaping the oral mycobiota: interactions of opportunistic fungi with oral bacteria and the host. Current Opinion in Microbiology 2015;26:65-70.

18. Thomas A, Thakur S, Mhambrey S. Comparison of the antimicrobial efficacy of chlorhexidine, sodium fluoride, fluoride with essential oils, alum, green tea, and garlic with lime mouth rinses on cariogenic microbes. Journal of International Society of Preventive \& Community Dentistry 2015;5(4): 302-308.

19. Jenkins S, Addy M, Wade W. The mechanism of action of chlorhexidine.A study of plaque growth on enamel inserts in vivo. Journal of Clinical Periodontology 1988;15(7): 415-424.

20. Visuri SR, Walsh JT, Jr., Wigdor HA. Erbium laser ablation of dental hard tissue: effect of water cooling. Lasers in Surgery and Medicine 1996;18(3):294-300.

21. Lizier NF, Kerkis A, Gomes CM, et al. Scaling-up of dental pulp stem cells isolated from multiple niches. PLoS One. 2012;7(6):e39885.

22. Kerkis I, Kerkis A, Dozortsev D, et al. Isolation and characterization of a population of immature dental pulp stem cells expressing OCT-4 and other embryonic stem cell markers. Cells, Tissues, Organs 2006;184(3-4):105-116.

23. Karamzadeh R, Eslaminejad MB, Aflatoonian R. Isolation, characterization and comparative differentiation of human dental pulp stem cells derived from permanent teeth by using two different methods. J Vis Exp 2012;24(69): 4372.

24. Patil R, Kumar BM, Lee WJ, et al. Multilineage potential and proteomic profiling of human dental stem cells derived from a single donor. Exp Cell Res. 2014;320(1):92-107. 

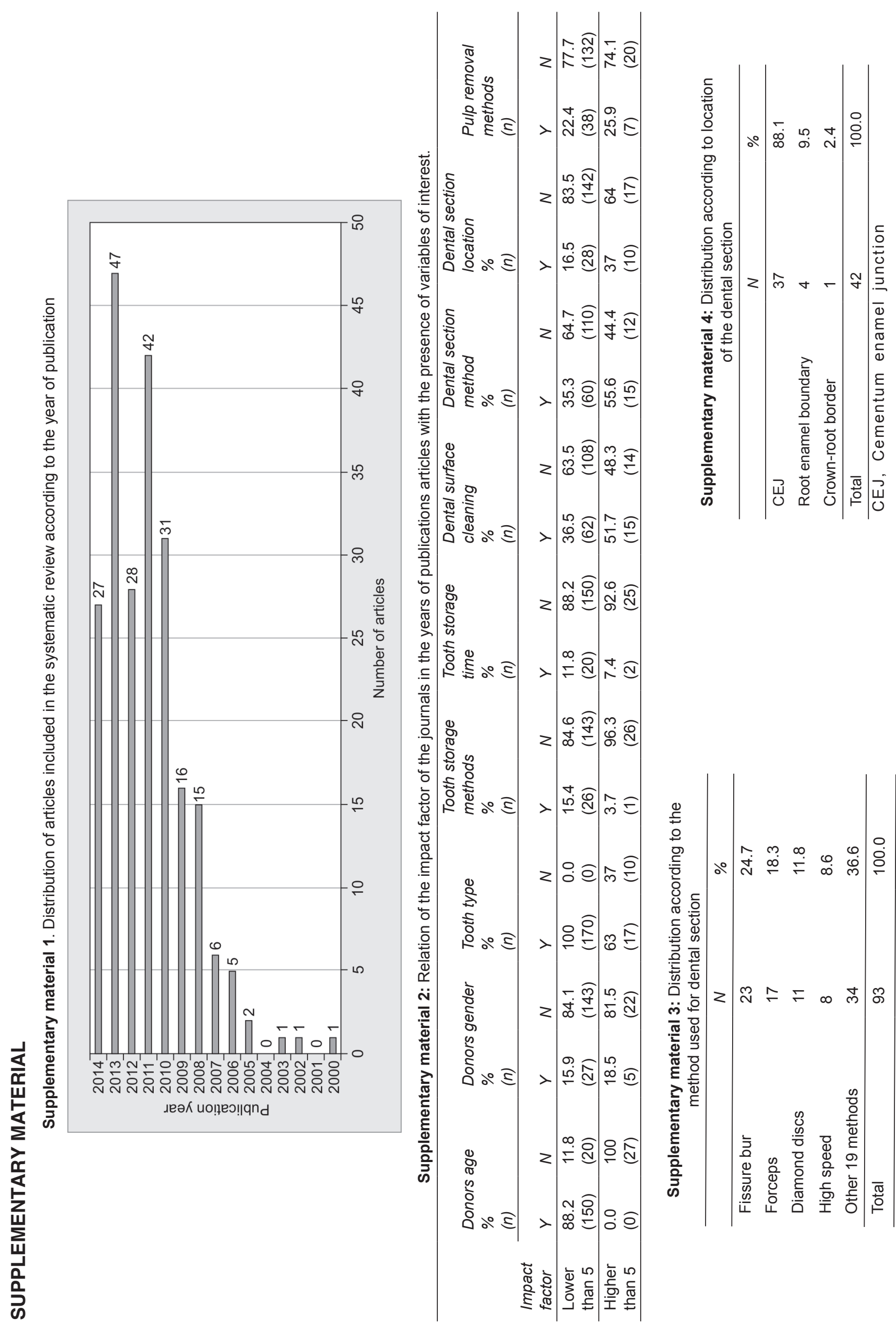

窇
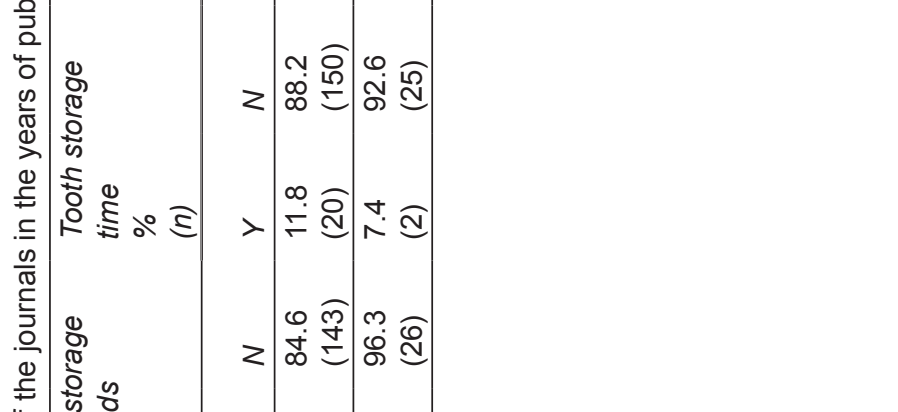

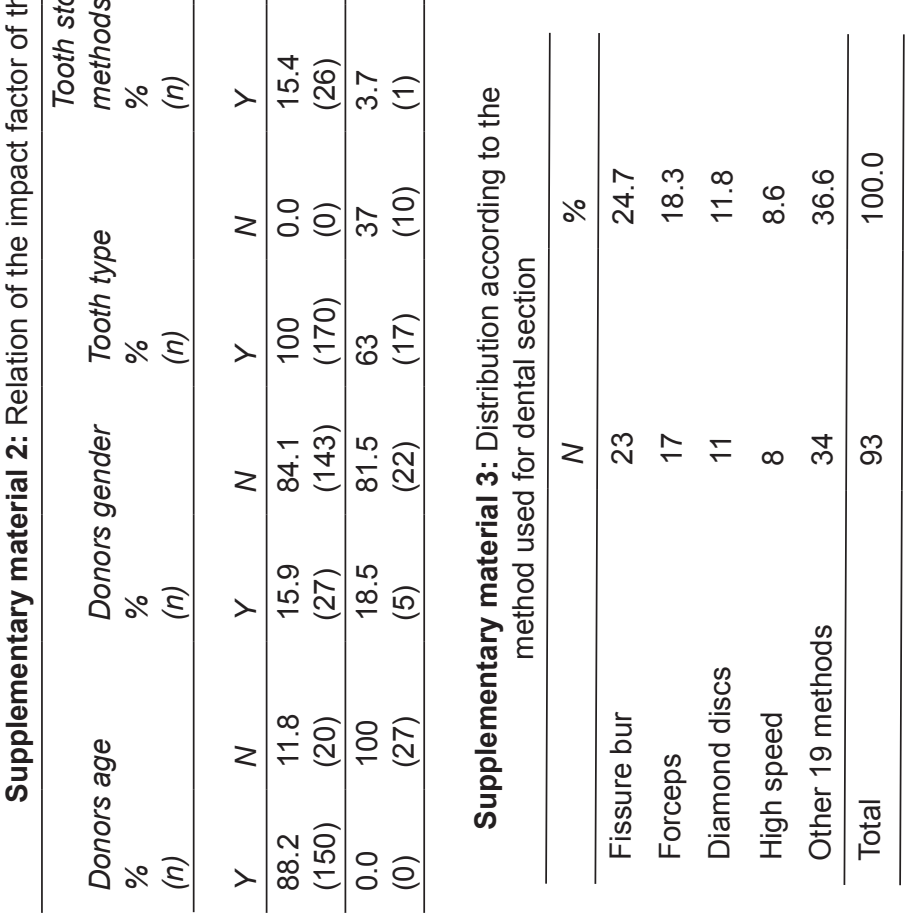

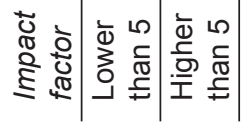




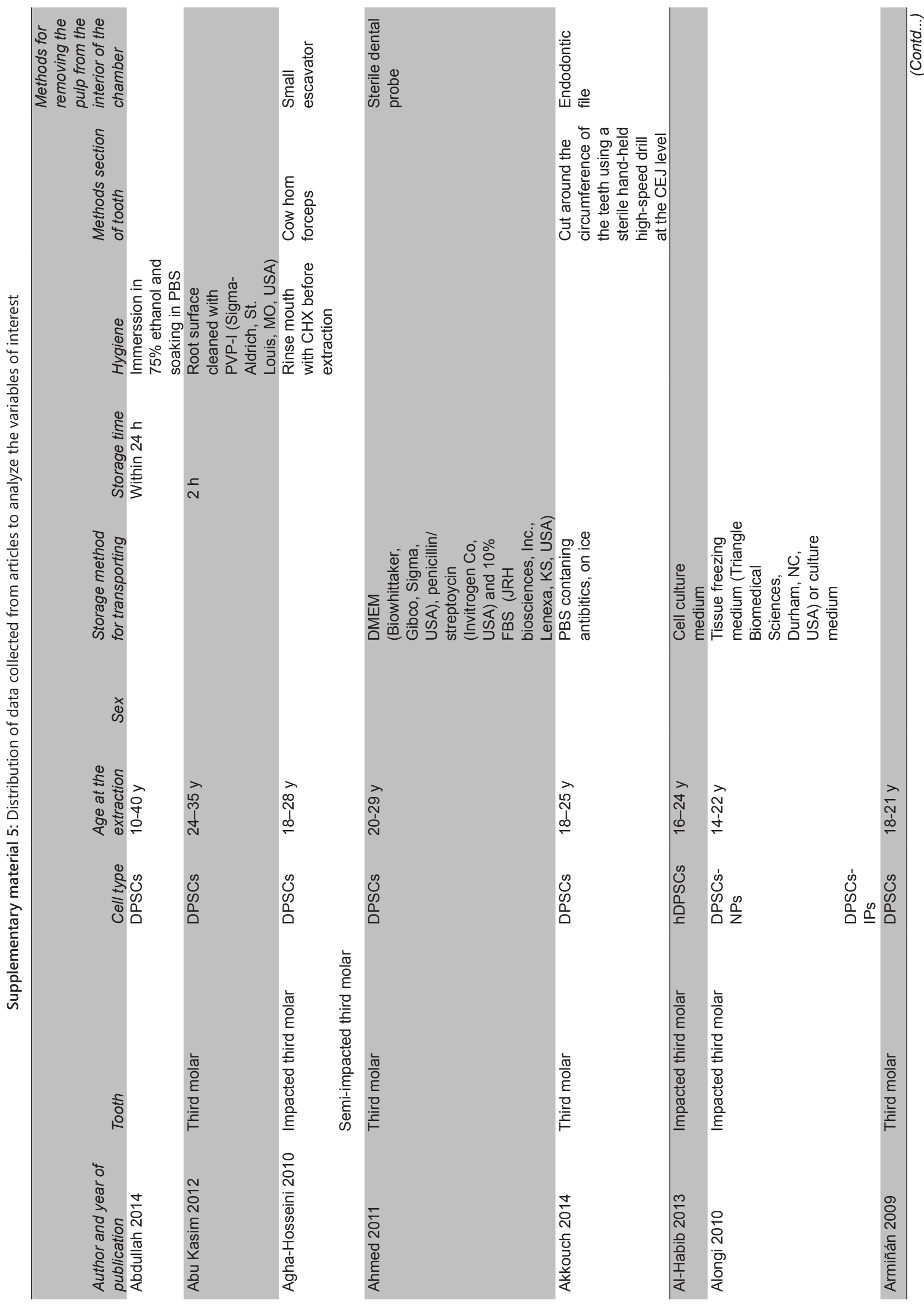




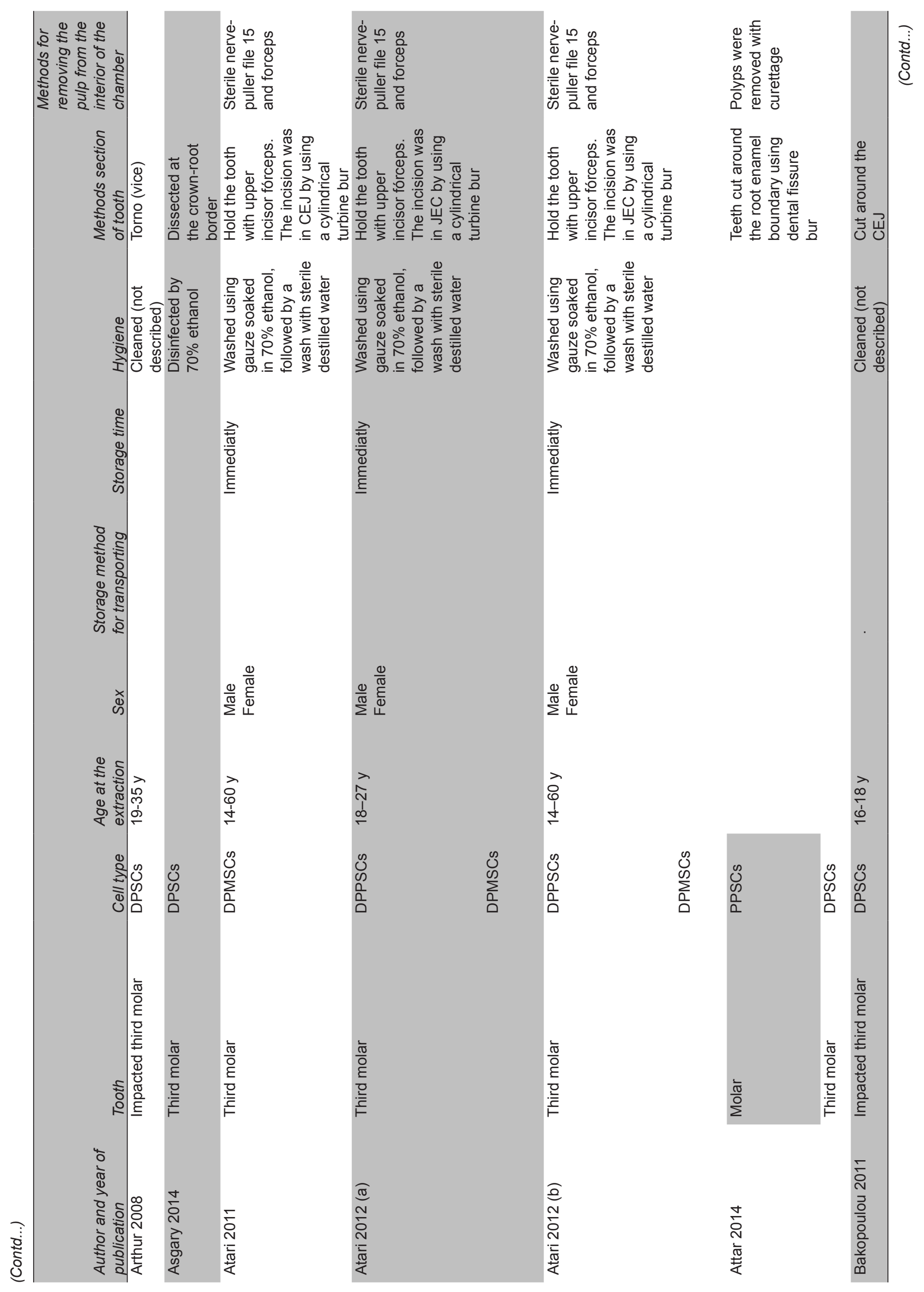




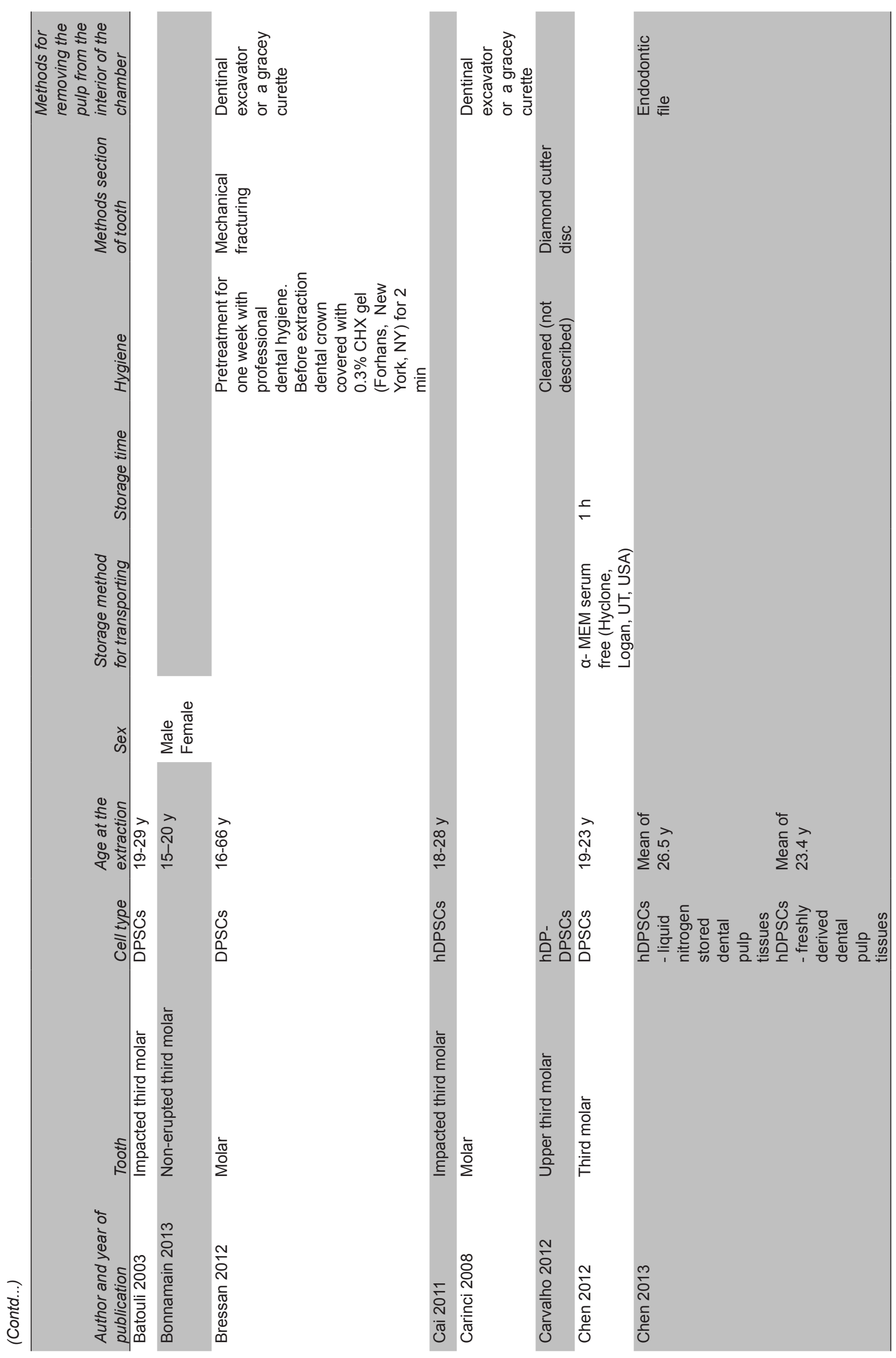




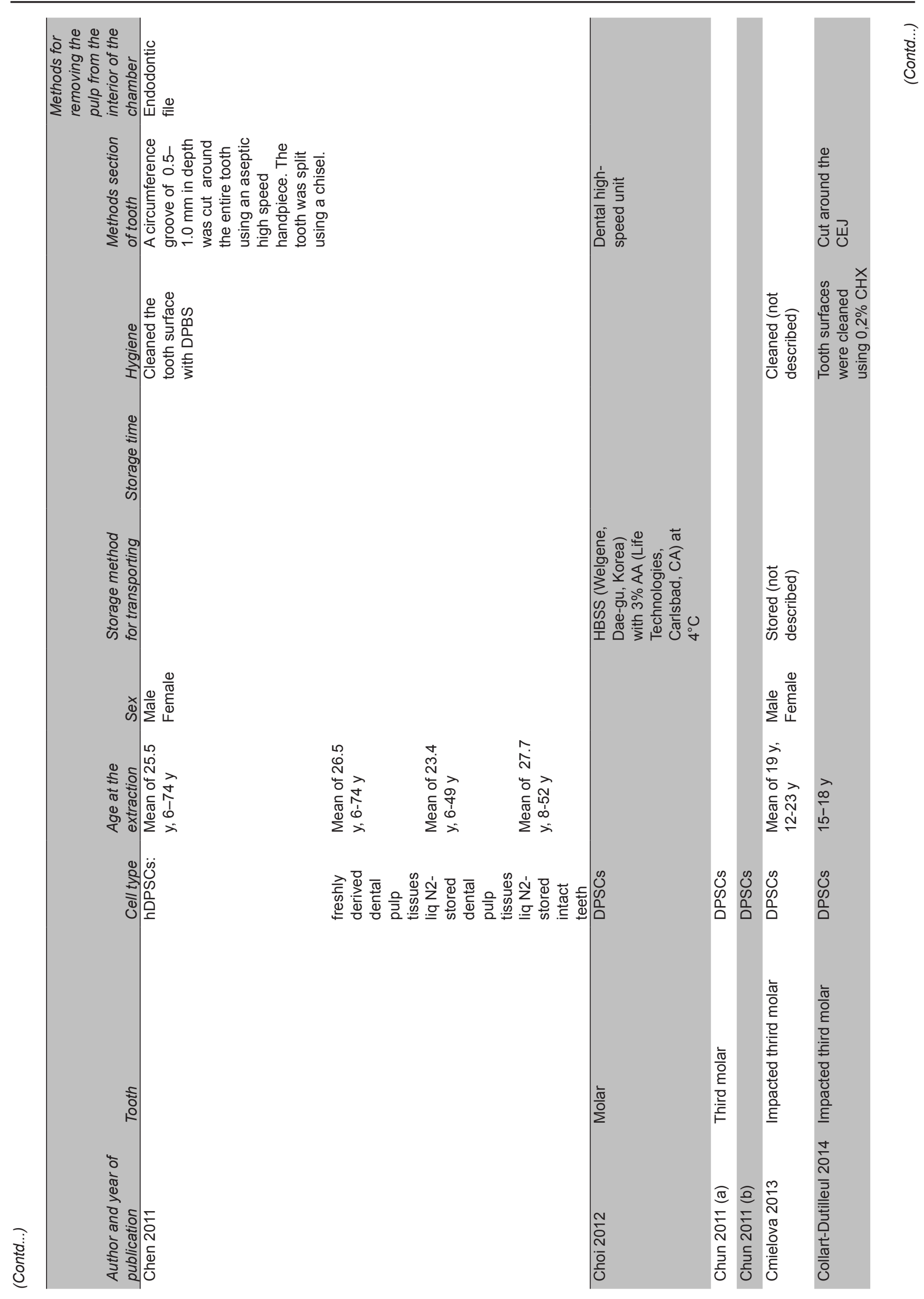




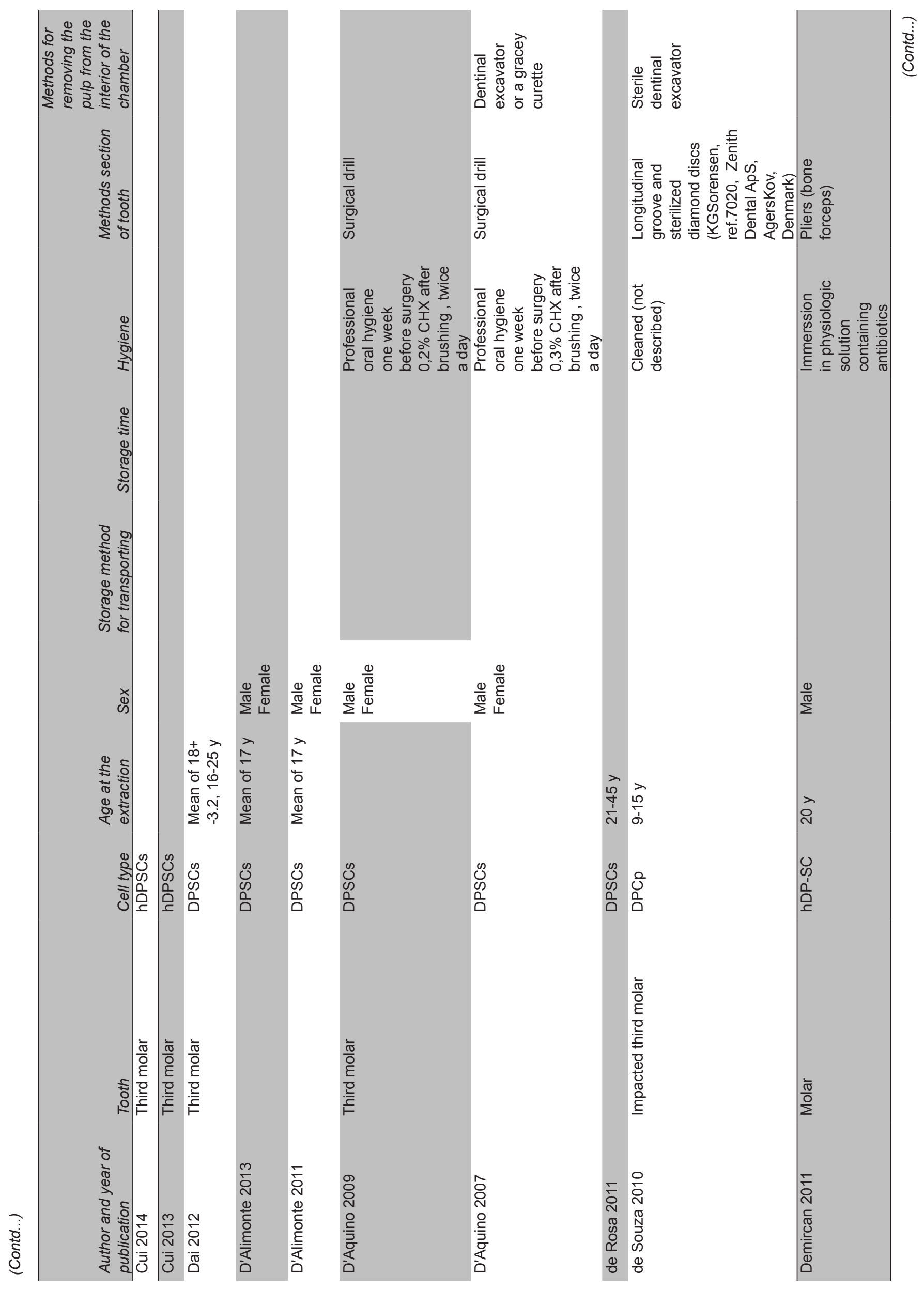




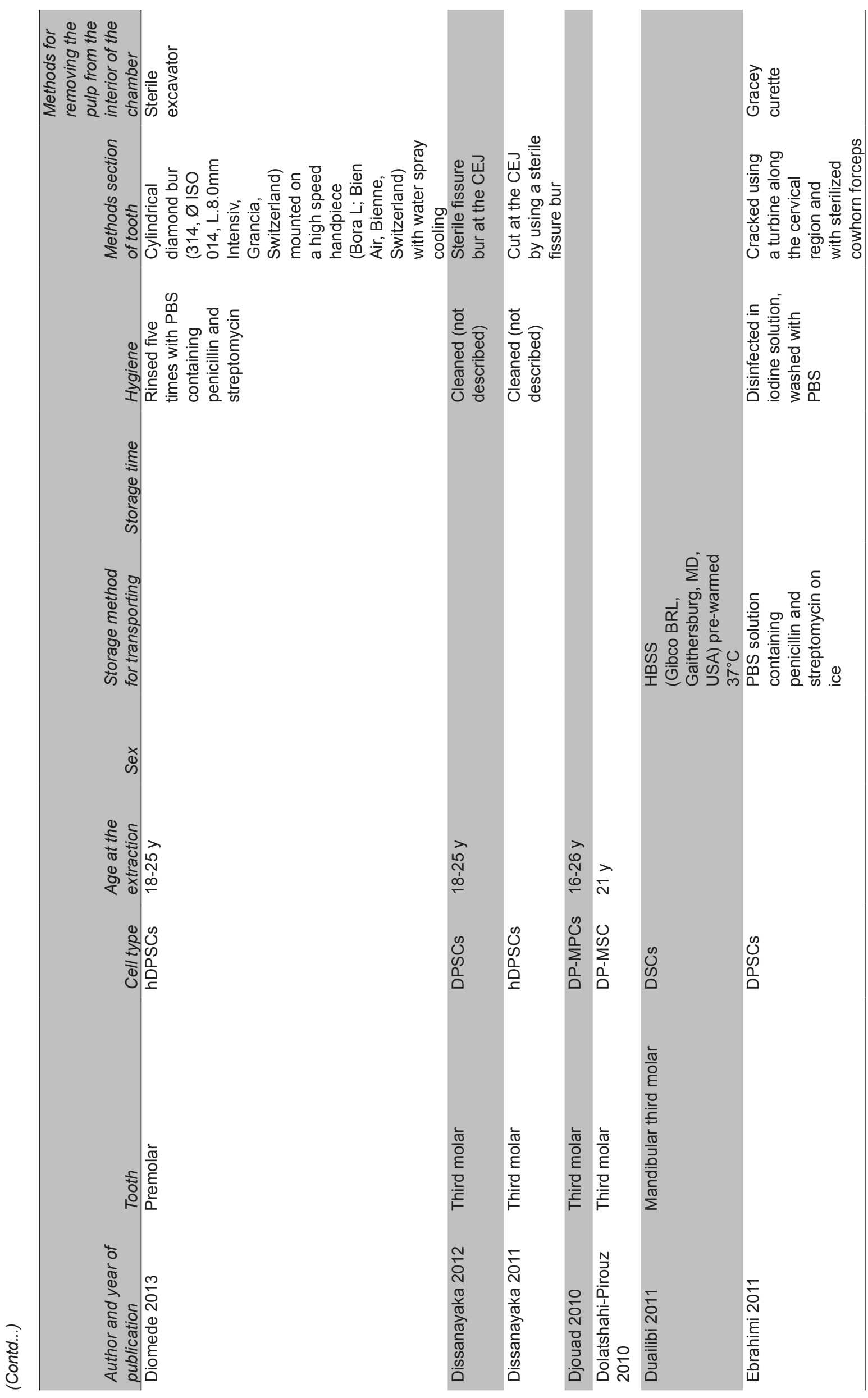




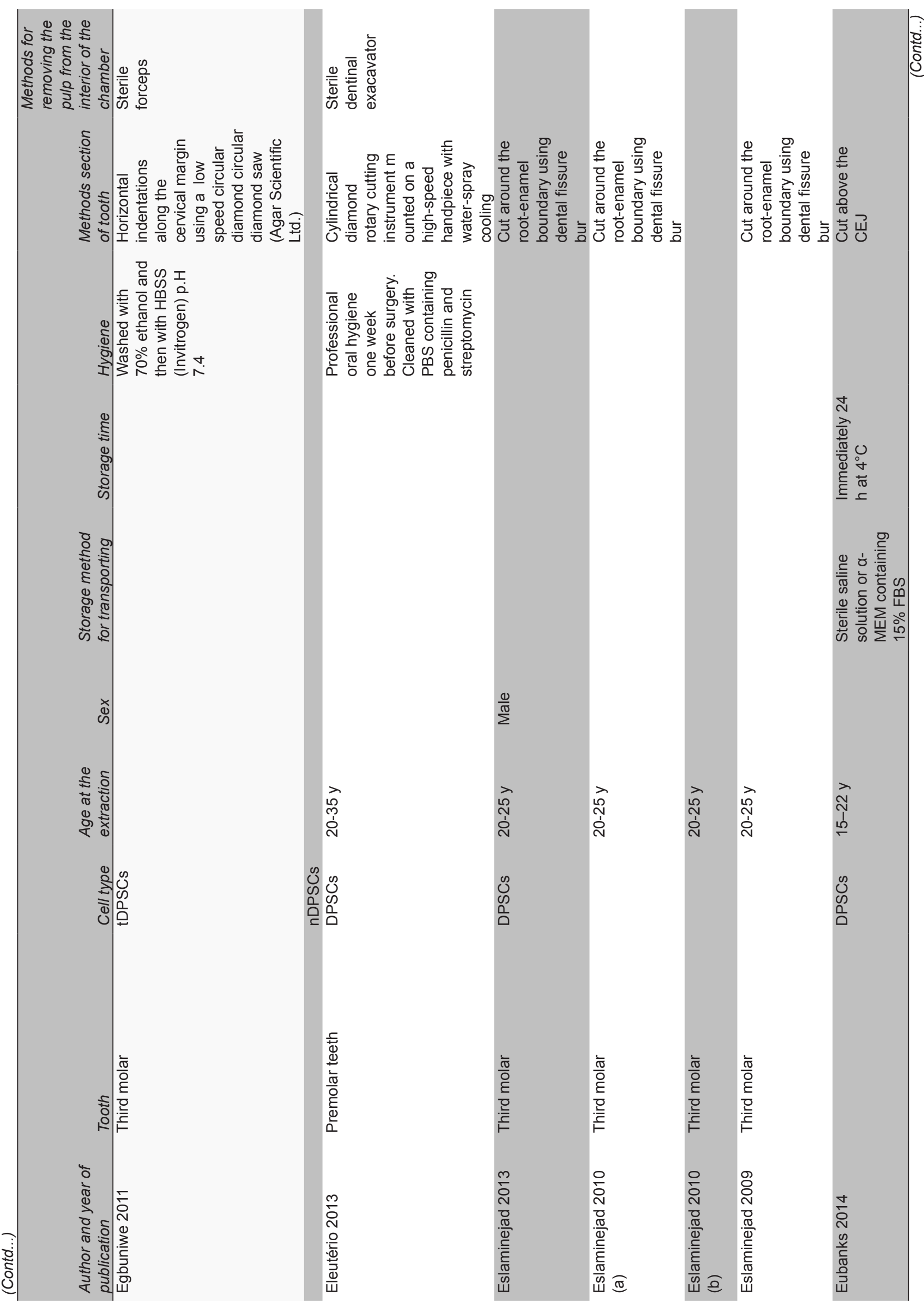




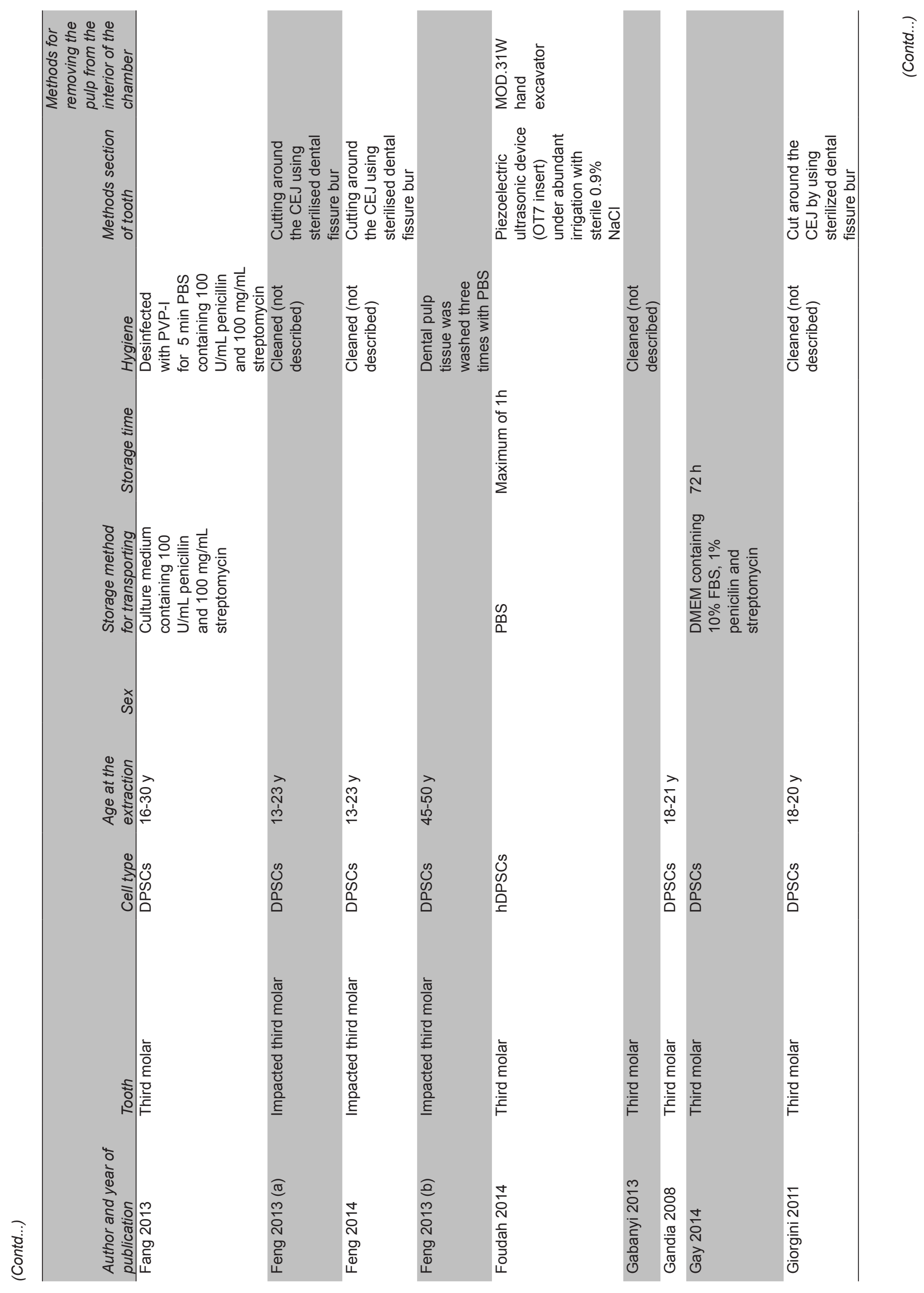




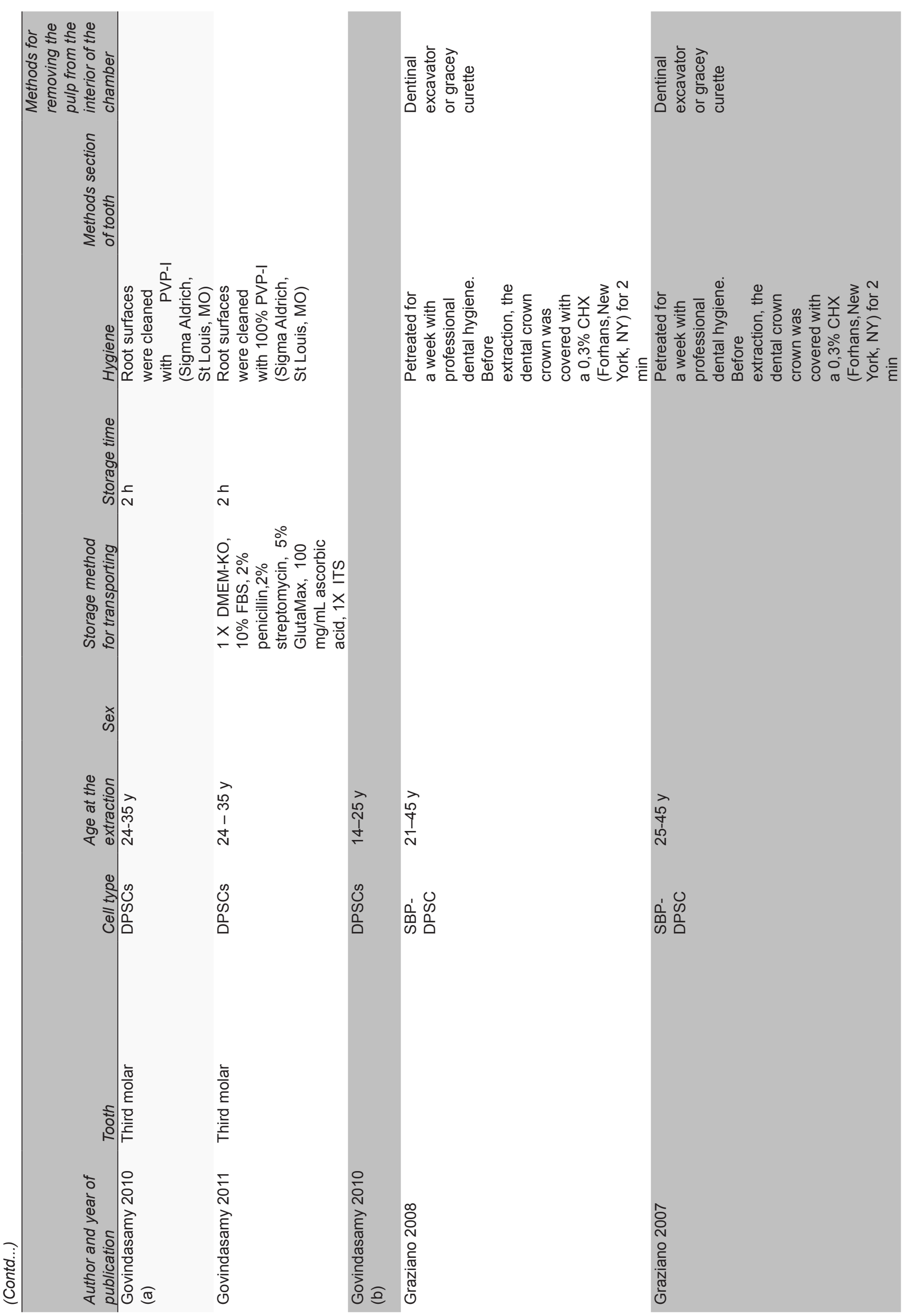

वे 


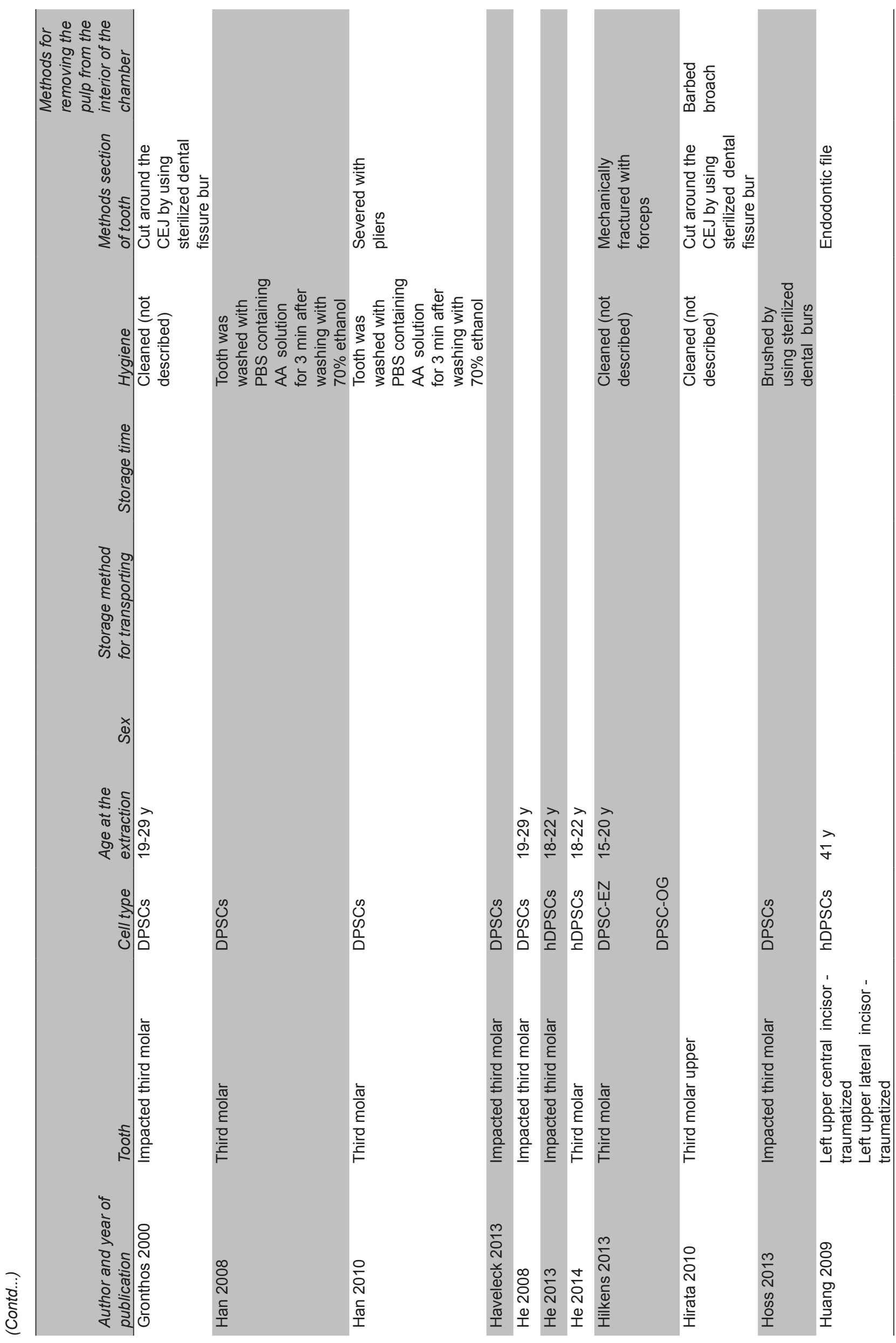




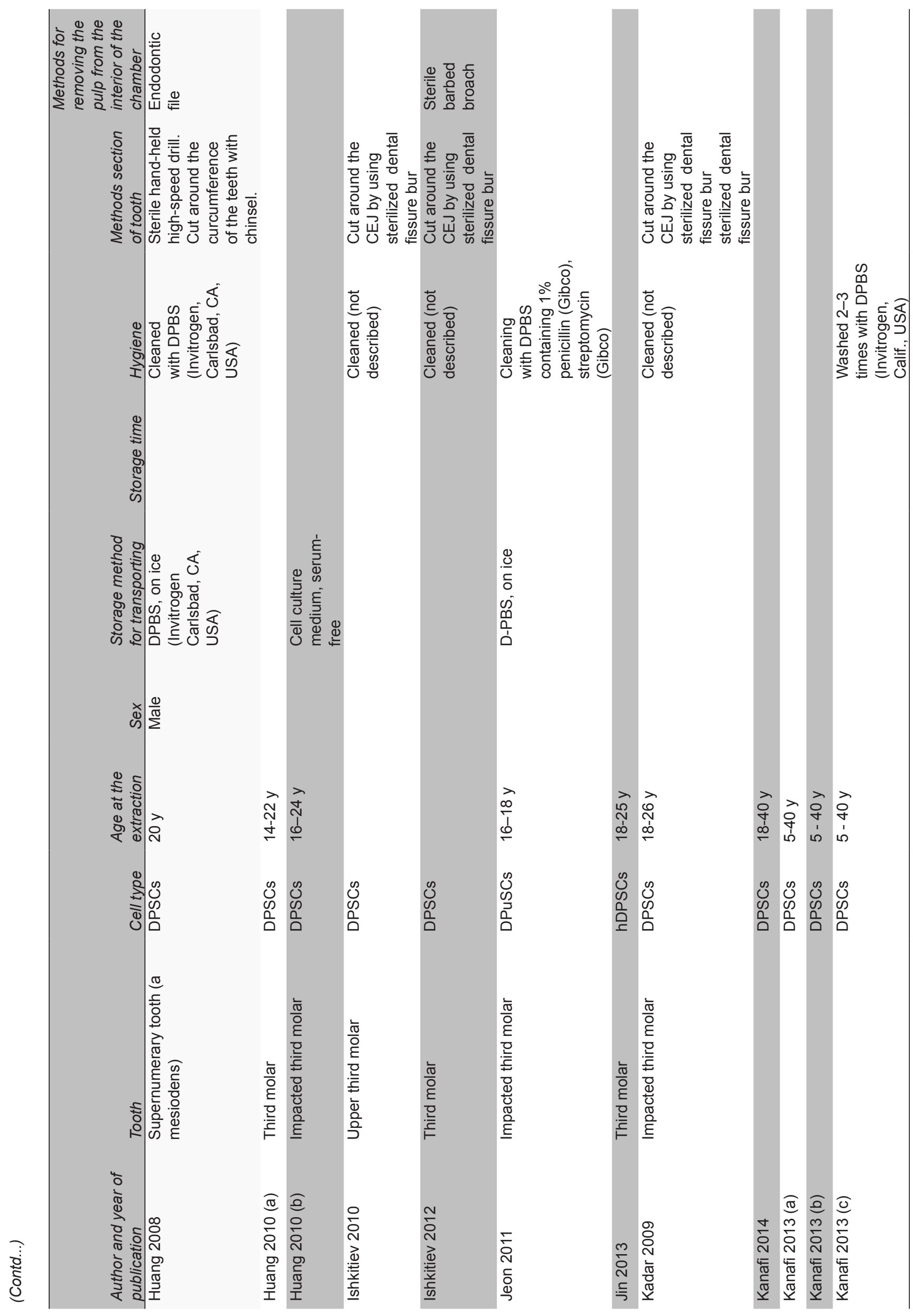




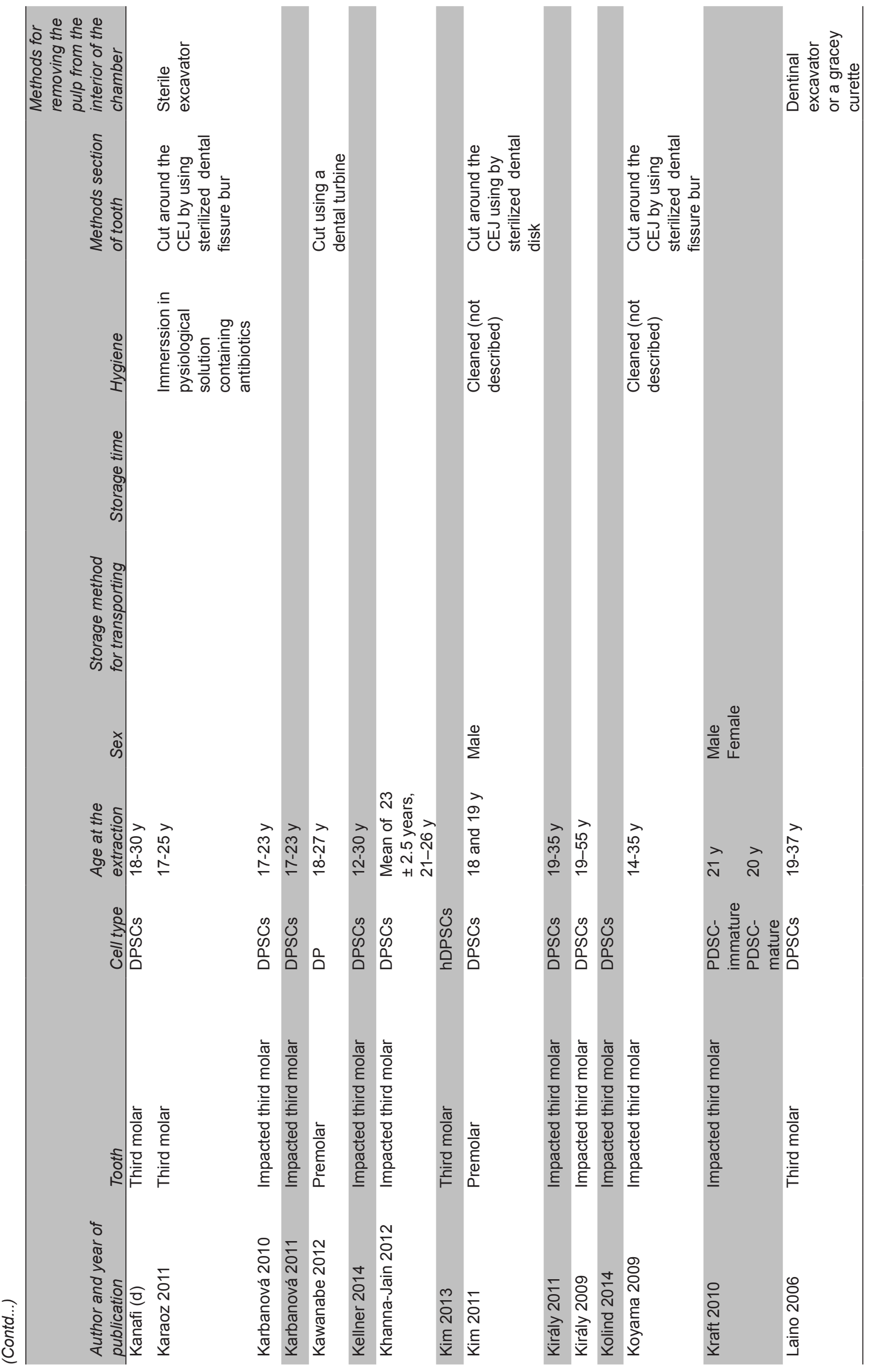




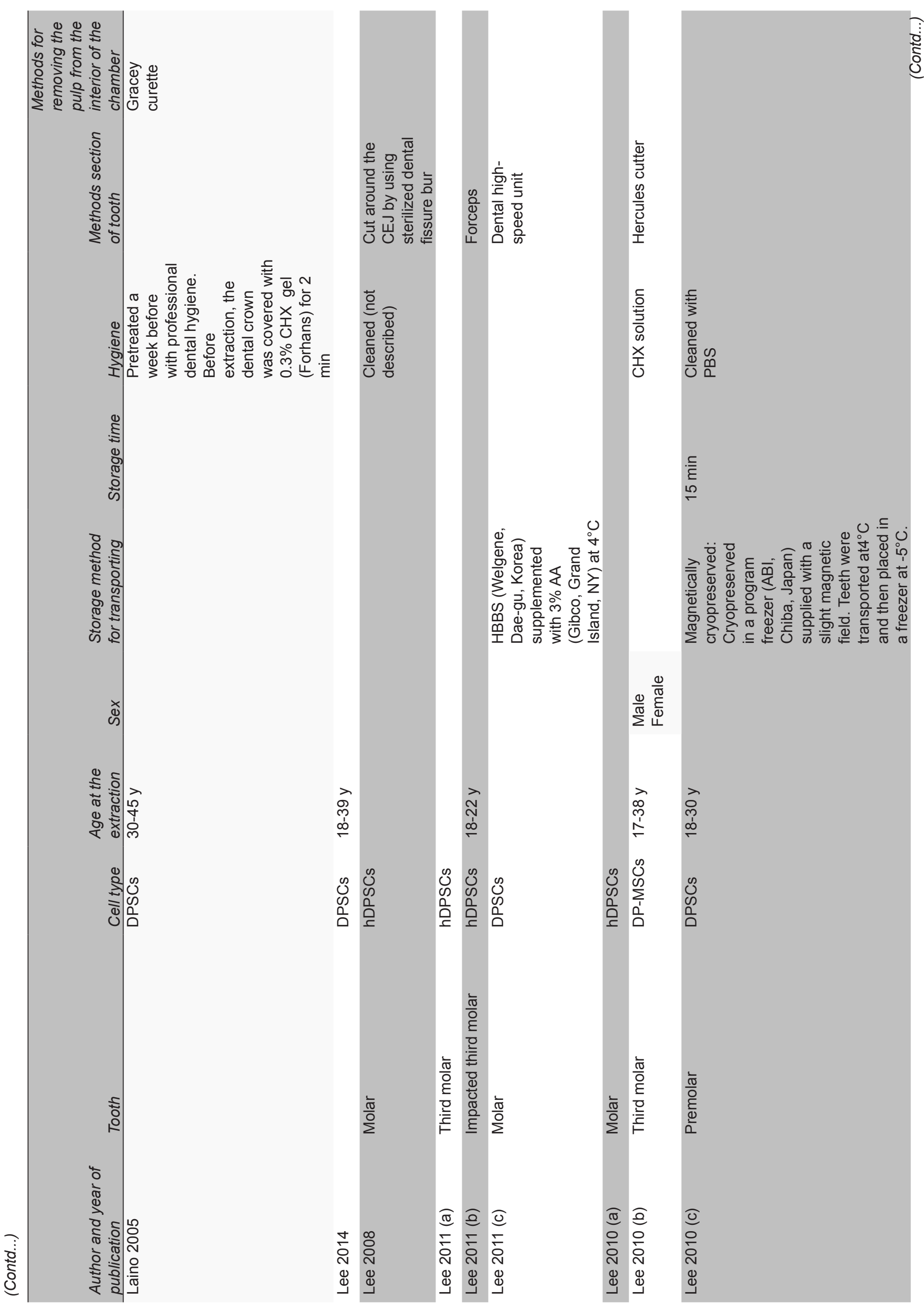




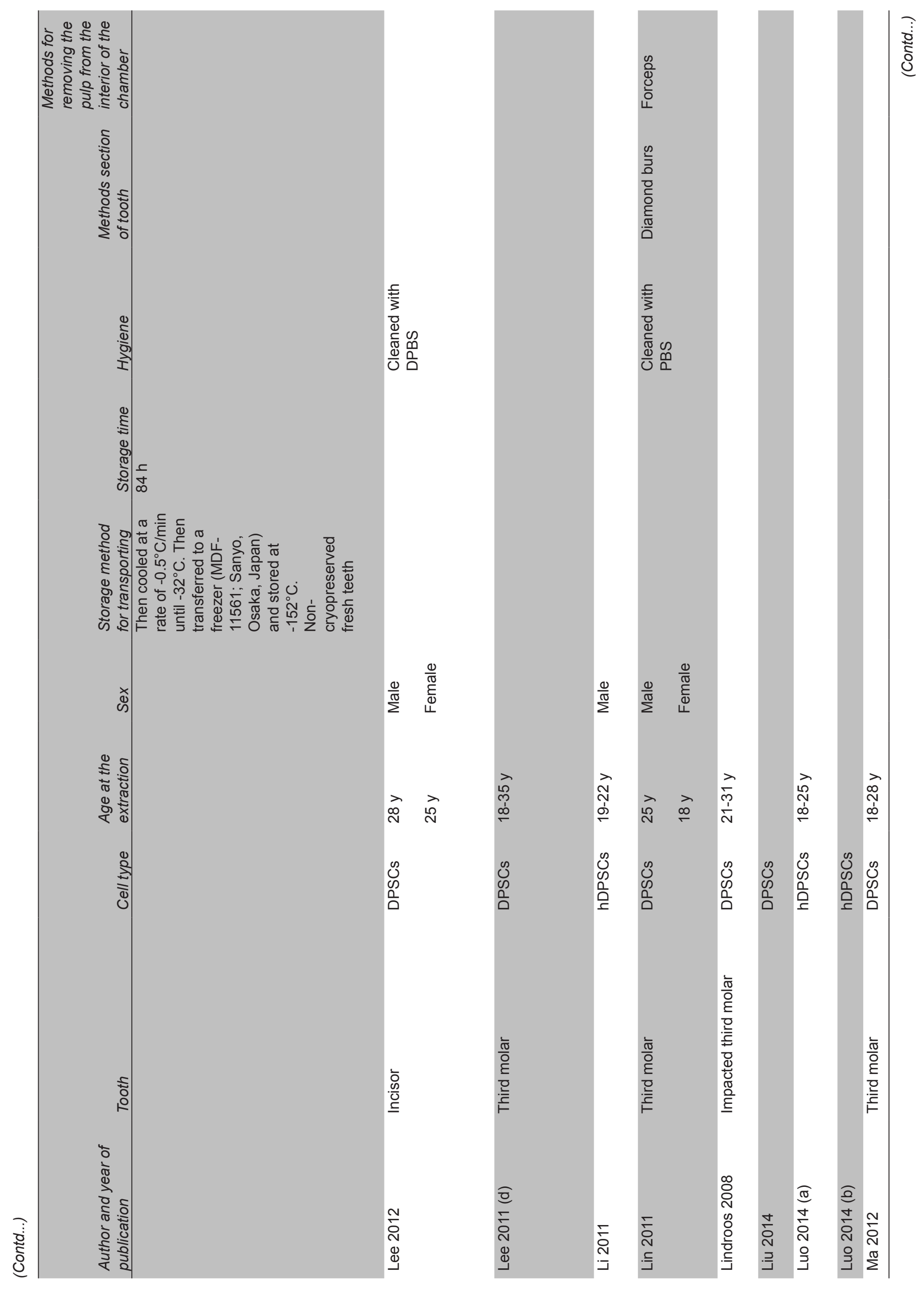




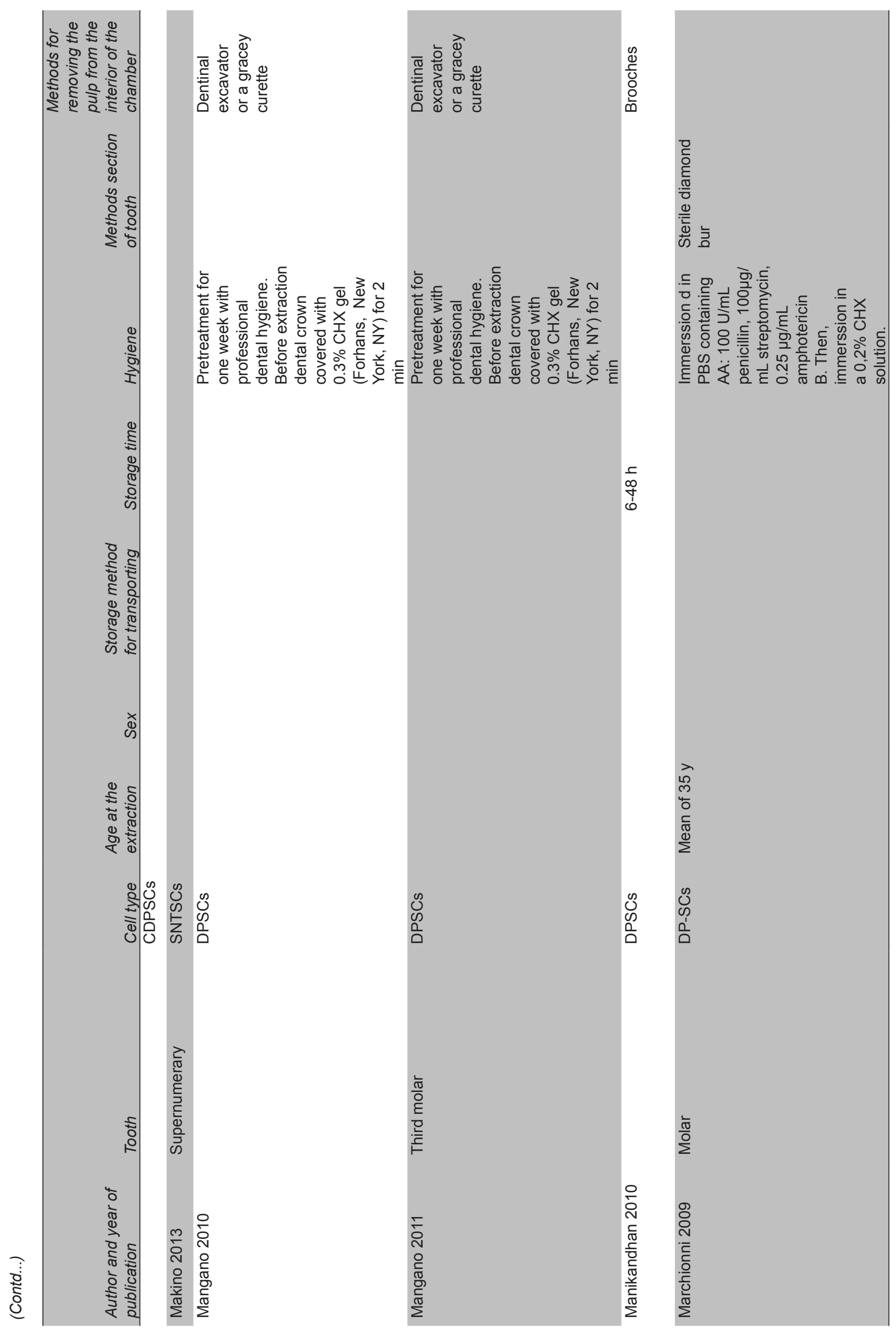

¿্ 


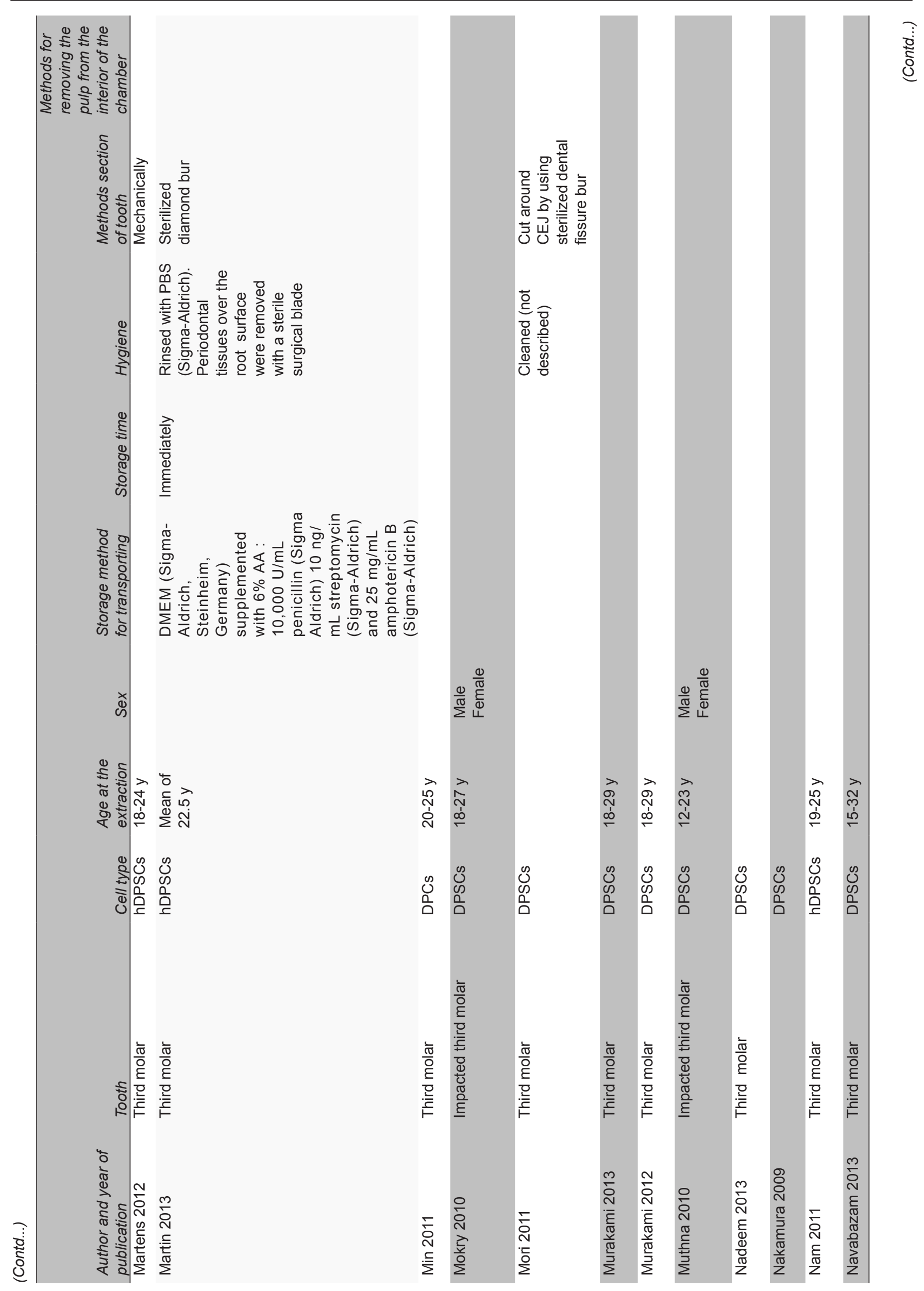




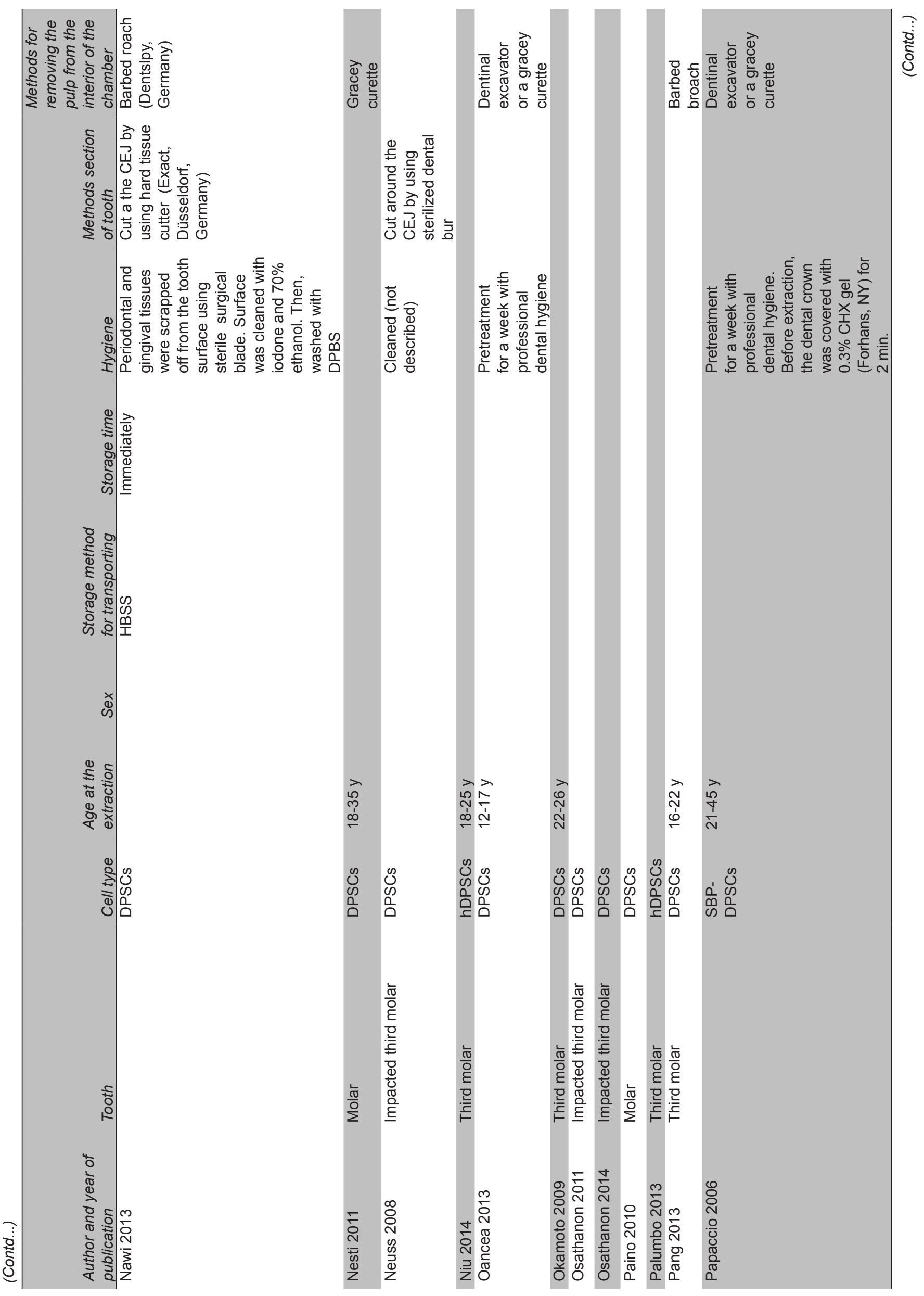




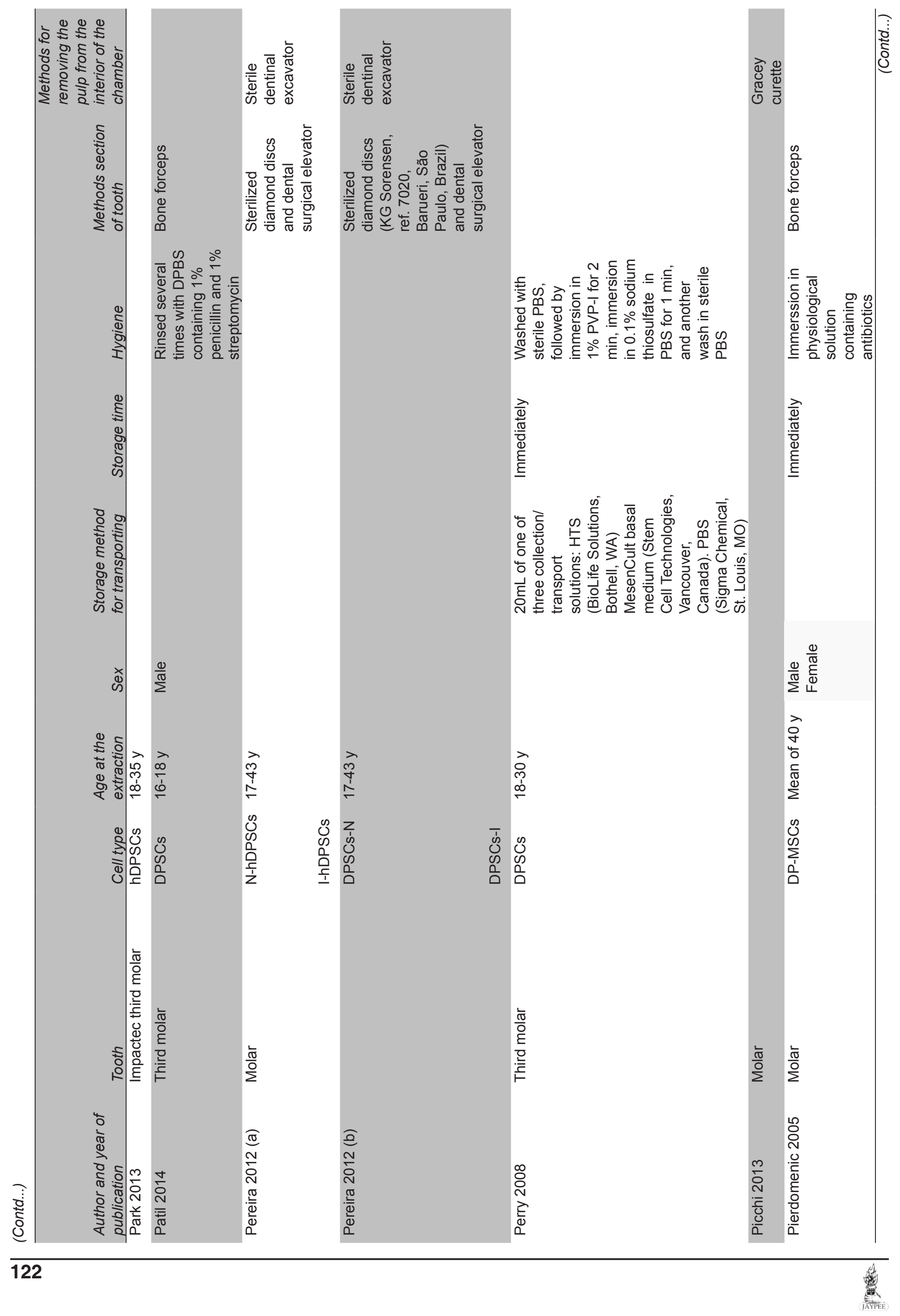




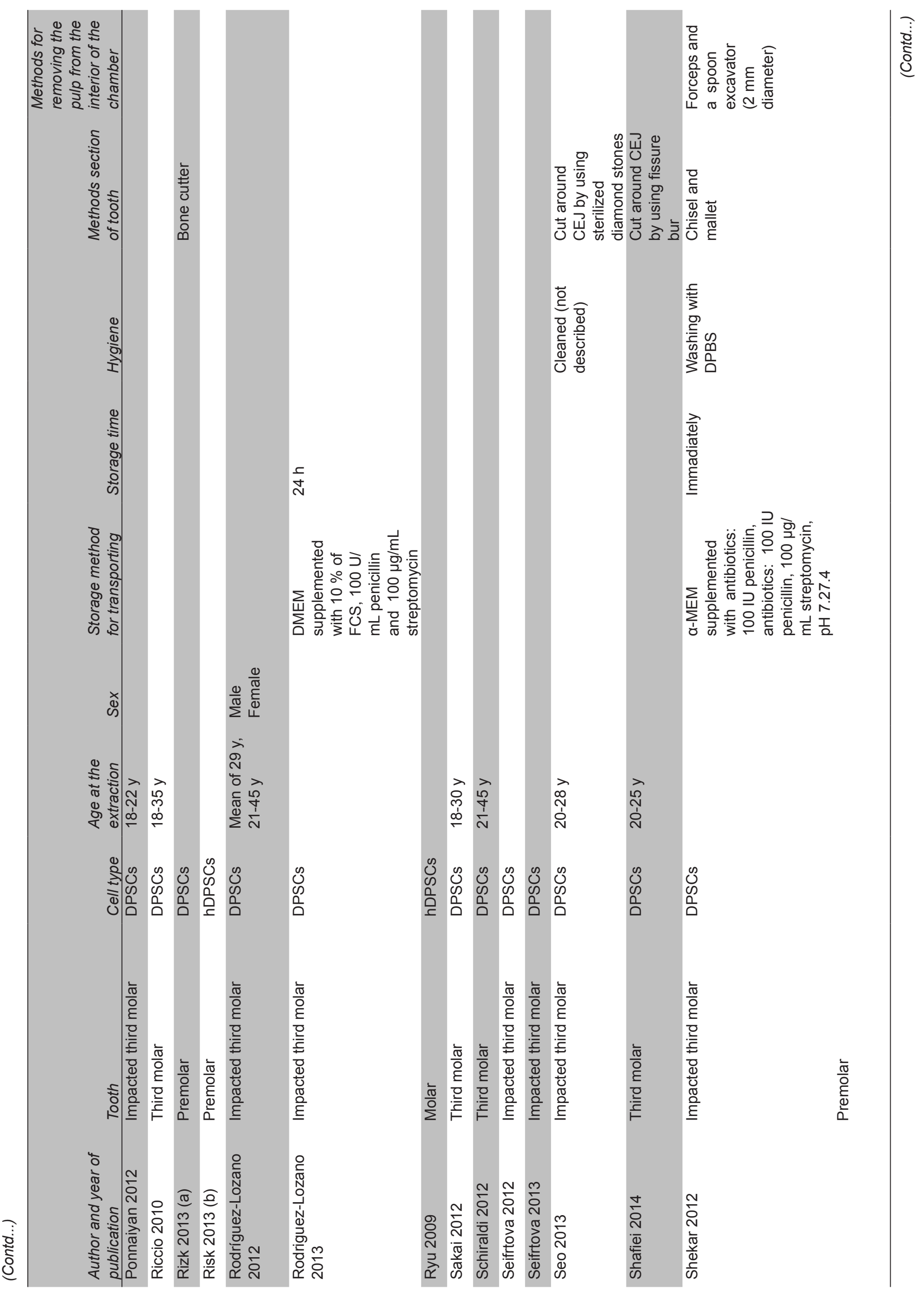




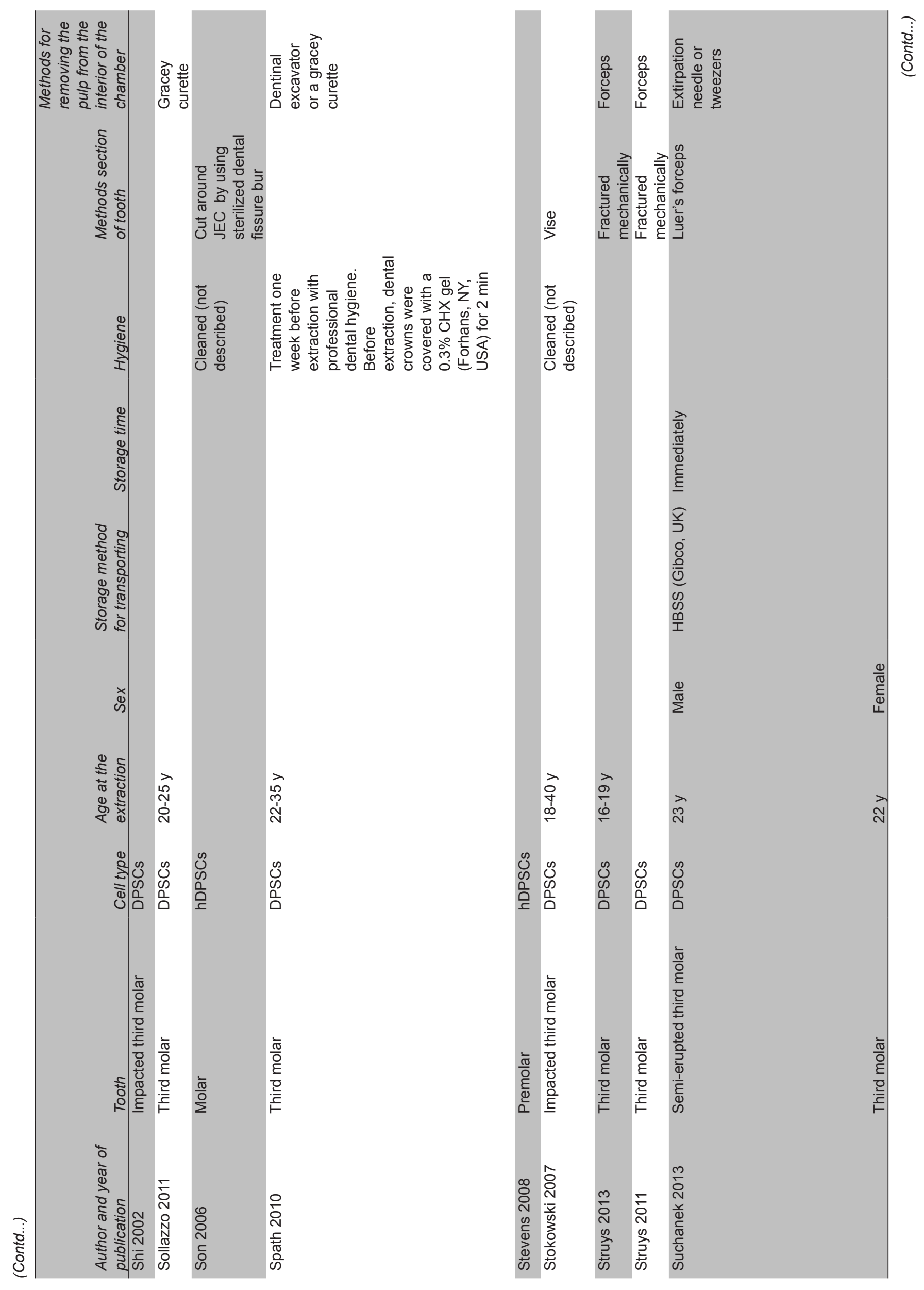




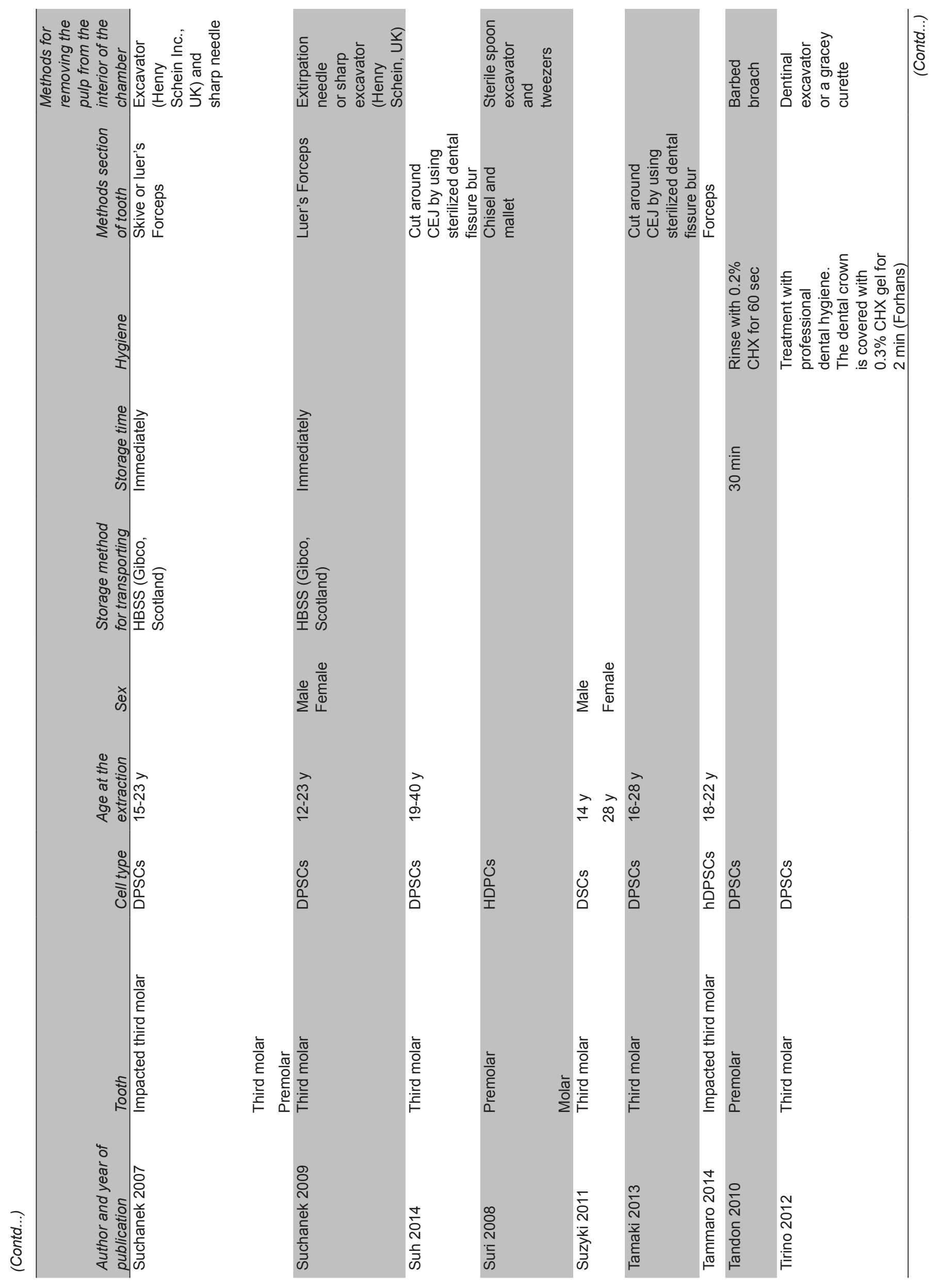




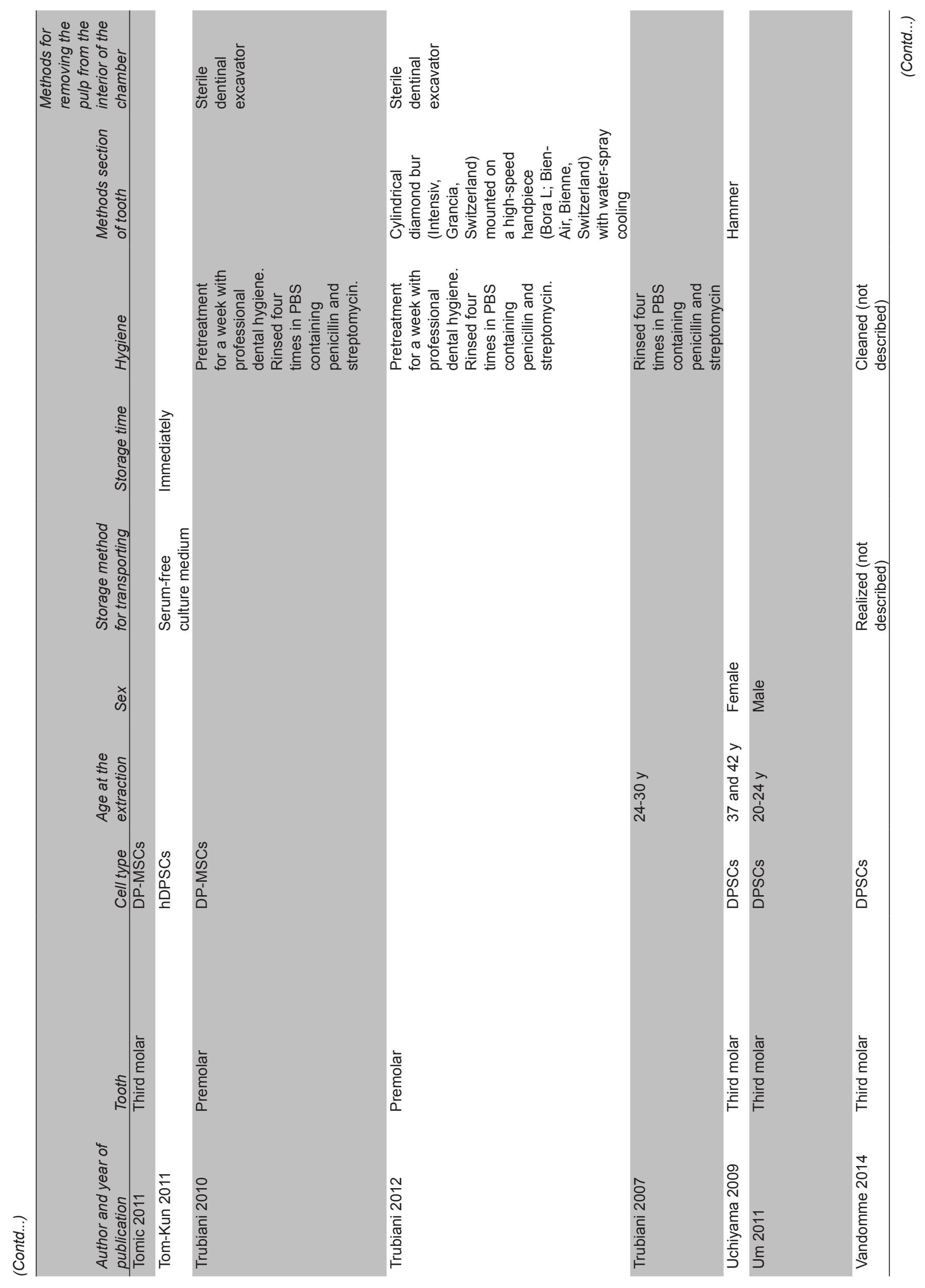




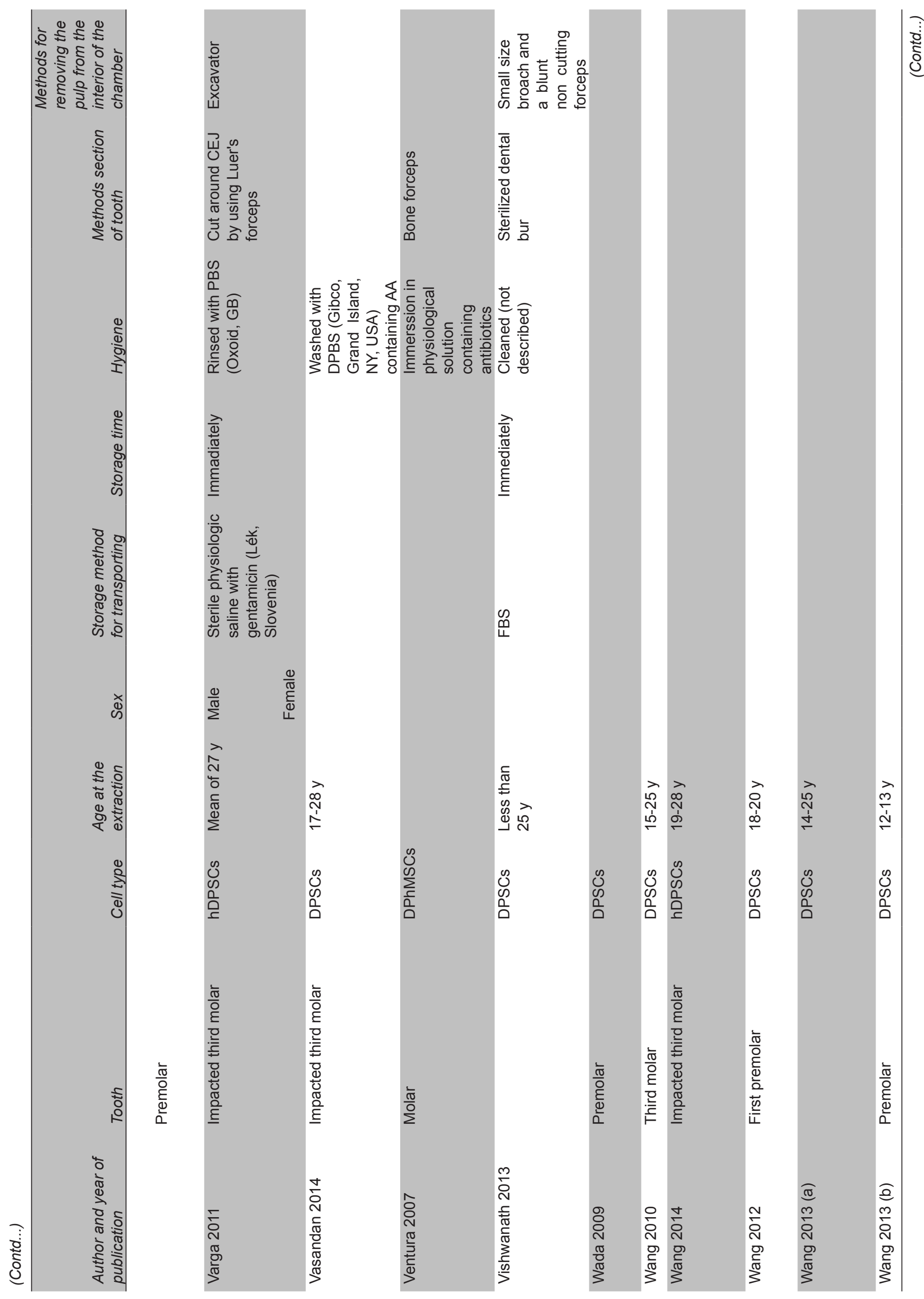




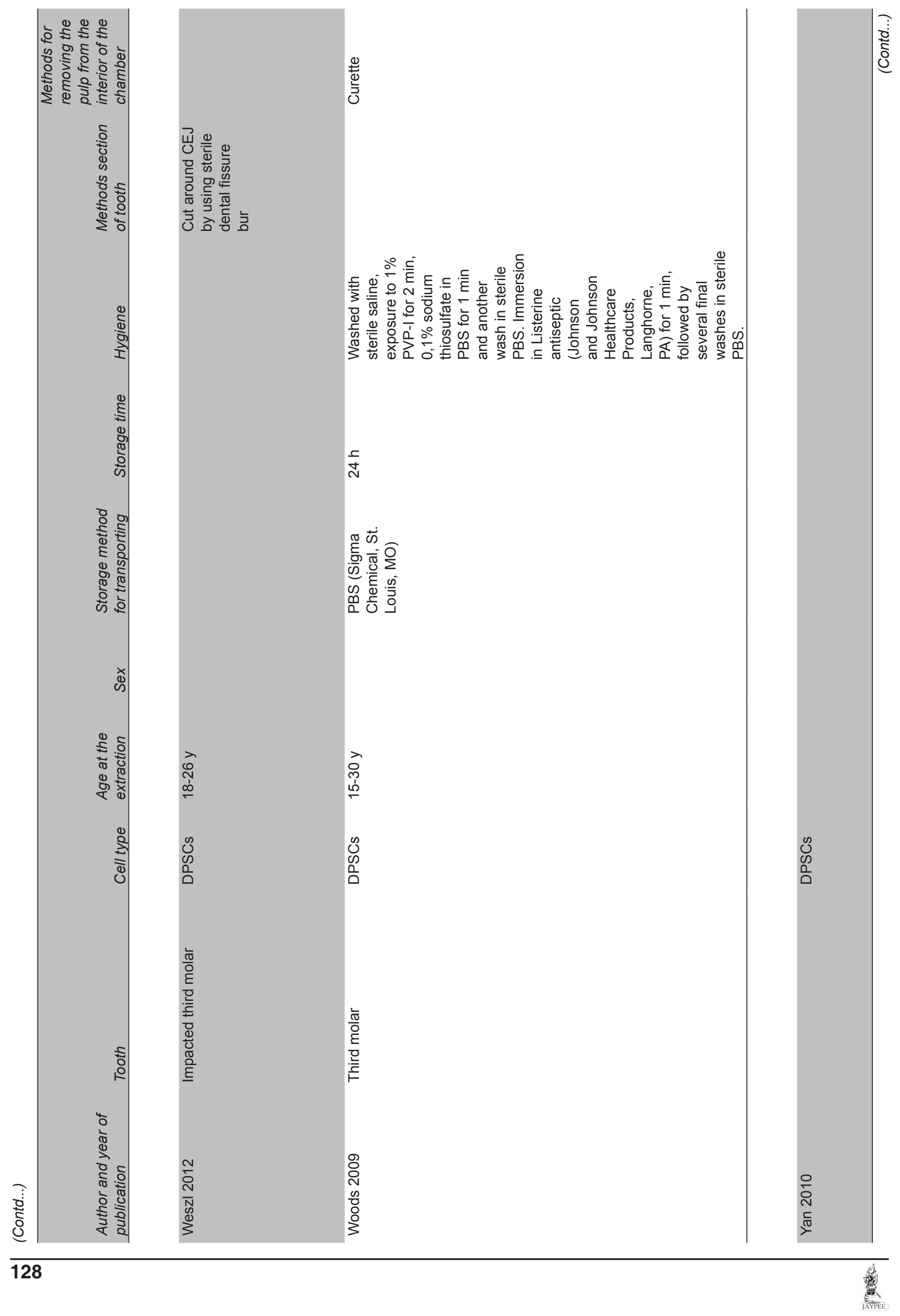




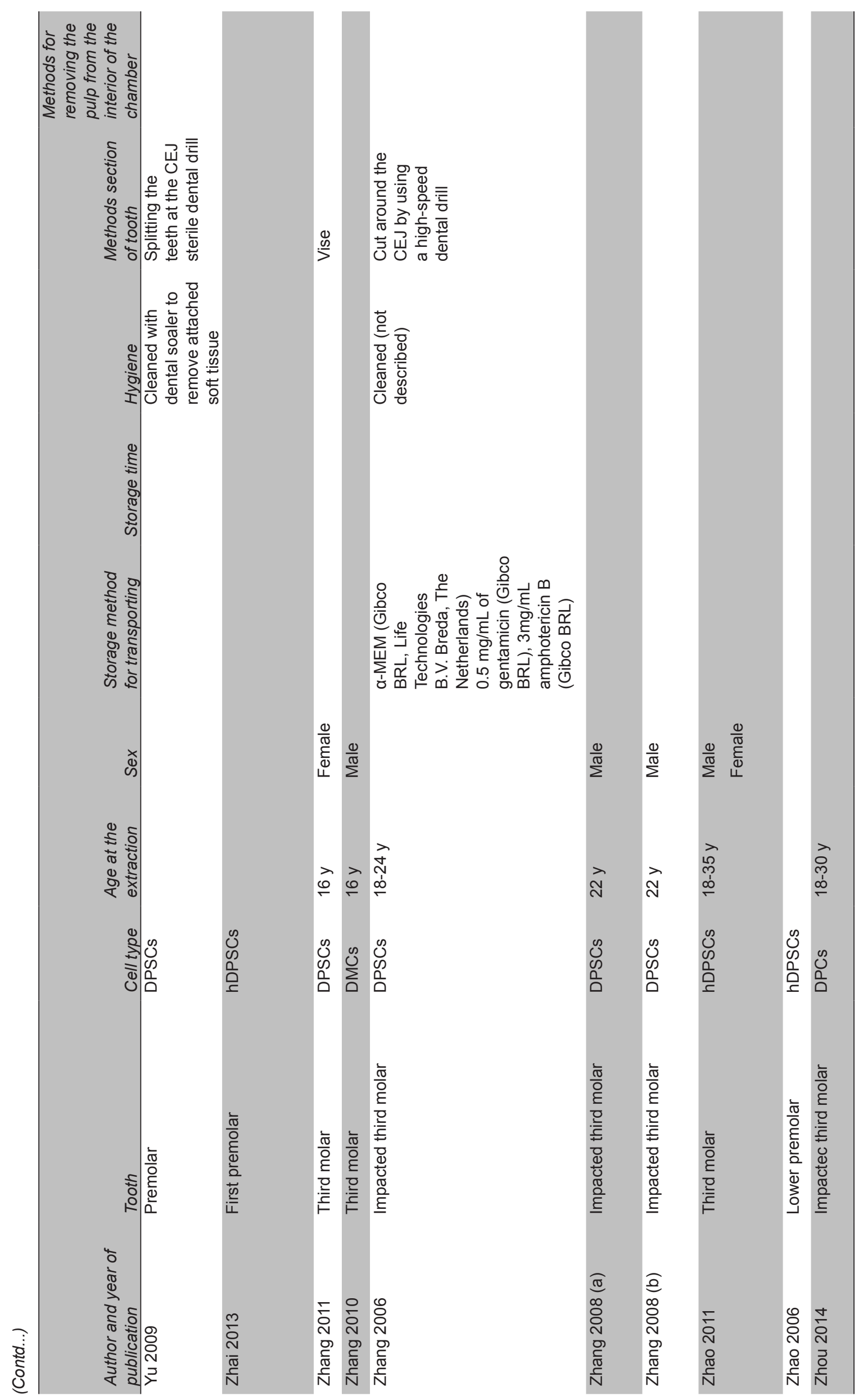




\section{BIBILIOGRAPHY}

1. Abdullah, M.F., et al., 2014. Proliferation rate of stem cells derived from human dental pulp and identification of differentially expressed genes. Cell Biol. Int. 38, 582-590.

2. Abu Kasim, N.H., et al., 2012. Unique molecular signatures influencing the biological function and fate of post-natal stem cells isolated from different sources. J. Tissue Eng. Regen. Med. 9, 252-266

3. Agha-Hosseini, F., et al., 2010. In vitro isolation of stem cells derived from human dental pulp. Clin Transplant. 24, 23-28.

4. Ahmed N.E.M.B., et al., 2011. Isolation of dental pulp stem cells and their in vitro differentiation into odontoblast-like cells. Macedonian Journal of Medical Sciences. 4, 253-260.

5. Akkouch, A., et al, 2014. Engineering bone tissue using human dental pulp stem cells and an osteogenic collagenhydroxyapatite-poly (L-lactide-co-epsilon-caprolactone) scaffold. J Biomater Appl. 28, 922-936.

6. Al-Habib, M., et al., 2012. Small molecules affect human dental pulp stem cell properties via multiple signaling pathways. Stem Cells Dev. 22, 2402-2413.

7. Alongi, D. J., et al., 2010. Stem/progenitor cells from inflamed human dental pulp retain tissue regeneration potential. Regen Med. 5, 617-631.

8. Arminan, A., et al., 2009 Cardiac differentiation is driven by NKX2.5 and GATA4 nuclear translocation in tissue-specific mesenchymal stem cells. Stem Cells Dev. 18, 907-918.

9. Arthur, A., et al., 2008. Adult human dental pulp stem cells differentiate toward functionally active neurons under appropriate environmental cues. Stem Cells. 26, 1787-1795.

10. Asgary, S., et al., 2014. Gene expression and cytokine release during odontogenic differentiation of human dental pulp stem cells induced by 2 endodontic biomaterials. J Endod. 40, 387-932.

11. Atari, M., et al., 2011. Isolation of pluripotent stem cells from human third molar dental pulp. Histol Histopathol. 26, 10571070.

12. Atari, M., et al., 2012. The enhancement of osteogenesis through the use of dental pulp pluripotent stem cells in 3D. Bone. 50, 930-941.

13. Atari, M., et al., 2012. Dental pulp of the third molar: a new source of pluripotent-like stem cells. J Cell Sci. 125, 3343-3356.

14. Attar, A., et al., 2014. Dental pulp polyps contain stem cells comparable to the normal dental pulps. J Clin Exp Dent. 6, 53-59.

15. Bakopoulou, A., et al., 2011. Comparative analysis of in vitro osteo/odontogenic differentiation potential of human dental pulp stem cells (DPSCs) and stem cells from the apical papilla (SCAP). Arch Oral Biol. 56, 709-721.

16. Batouli, S., et al., 2003 Comparison of stem-cell-mediated osteogenesis and dentinogenesis. J Dent Res. 82, 976-981.

17. Bonnamain, V., et al., 2013. Human dental pulp stem cells cultured in serum-free supplemented medium. Front Physiol. 4:1-9.

18. Bressan, E., et al., 2012. Donor age-related biological properties of human dental pulp stem cells change in nanostructured scaffolds. PLoS One. 7, 1-12.

19. Cai, X., et al., 2011. Uniaxial cyclic tensile stretch inhibits osteogenic and odontogenic differentiation of human dental pulp stem cells. J Tissue Eng Regen Med. 5, 347-353.

20. Carinci, F., et al., 2008. Comparison between genetic portraits of osteoblasts derived from primary cultures and osteoblasts obtained from human pulpar stem cells. J Craniofac Surg. 19, 616-625.

21. Carvalho, A., et al., 2012. Micropatterned silica thin films with nanohydroxyapatite micro-aggregates for guided tissue regeneration. Dent Mater. 28, 1250-1260.

22. Chen, Y.K., et al., 2013. Human dental pulp stem cells derived from cryopreserved dental pulp tissues of vital extracted teeth with disease demonstrate hepatic-like differentiation. J Tissue Eng Regen Med. 10, 6, 475-485.

23. Chen, B., et al., 2012. The effects of human platelet lysate on dental pulp stem cells derived from impacted human third molars. Biomaterials33, 5023-5035.

24. Chen, Y.K., et al., 2011. Human dental pulp stem cells derived from different cryopreservation methods of human dental pulp tissues of diseased teeth. J Oral Pathol Med. 40, 793-800.

25. Choi, Y.J., et al., 2012. Cell-penetrating superoxide dismutase attenuates oxidative stress-induced senescence by regulating the p53-p21(Cip1) pathway and restores osteoblastic differentiation in human dental pulp stem cells. Int J Nanomedicine. 7, 5091-106.

26. Chun, S.Y., et al., 2011. Composite Scaffold with Demineralized Dentin Particle and Poly(Lactic Co-Glycolic Acid) for Cranial Bone Regeneration. Tissue Engineering and Regenerative Medicine. 8, 306-313.

27. Chun, S.Y., et al., 20011. Analysis of the soluble human tooth proteome and its ability to induce dentin/tooth regeneration. Tissue Eng Part A. 17, 181-191.

28. Cmielova, J., et al., 2013. The effect of ATM kinase inhibition on the initial response of human dental pulp and periodontal ligament mesenchymal stem cells to ionizing radiation. Int J Radiat Biol. 89, 501-511.

29. Collart-Dutilleul, P.Y., et al., 2014. Adhesion and proliferation of human mesenchymal stem cells from dental pulp on porous silicon scaffolds. ACS Appl Mater Interfaces. 6, 1719-1728.

30. Cui, L., et al., 2014. The role of integrin-alpha5 in the proliferation and odontogenic differentiation of human dental pulp stem cells. J Endod. 40, 235-240.

31. Cui, L., et al., 2013. The effect of TRPM7 suppression on the proliferation, migration and osteogenic differentiation of human dental pulp stem cells. Int Endod J. 47, 6, 583-593

32. Dai, J., et al., 2012. The effect of co-culturing costal chondrocytes and dental pulp stem cells combined with exogenous FGF9 protein on chondrogenesis and ossification in engineered cartilage. Biomaterials. 33, 7699-7711.

33. D'Alimonte, I., et al., 2013. Adenosine A(1) receptor stimulation enhances osteogenic differentiation of human dental pulpderived mesenchymal stem cells via WNT signaling. Stem Cell Research. 11, 611-624.

34. D'Alimonte, I., et al., 2011. Vascular Endothelial Growth Factor Enhances in Vitro Proliferation and Osteogenic Differentiation of Human Dental Pulp Stem Cells. Journal of Biological Regulators and Homeostatic Agents. 25, 57-69.

35. d'Aquino, R., et al., 2009. Human mandible bone defect repair by the grafting of dental pulp stem/progenitor cells and collagen sponge biocomplexes. Eur Cell Mater. 18, 75-83.

36. d'Aquino, R., et al., 2007. Human postnatal dental pulp cells co-differentiate into osteoblasts and endotheliocytes: a pivotal synergy leading to adult bone tissue formation. Cell Death Differ. 14, 1162-1171.

37. De Rosa, A.,et al., 2011. Amniotic fluid-derived mesenchymal stem cells lead to bone differentiation when cocultured with dental pulp stem cells. Tissue Eng Part A. 17, 645-653.

38. de Souza, L.M., et al., 2010. Comparative isolation protocols and characterization of stem cells from human primary and permanent teeth pulp. Brazilian Journal of Oral Sciences. 9, 427-433. 
39. Demircan, P.C., et al., 2011. Immunoregulatory effects of human dental pulp-derived stem cells on T cells: comparison of transwell co-culture and mixed lymphocyte reaction systems. Cytotherapy. 13, 1205-1220.

40. Diomede, F., et al., 2013. Pro-inflammatory cytokine release and cell growth inhibition in primary human oral cells after exposure to endodontic sealer. Int Endod J. 47, 9, 864-872.

41. Dissanayaka, W.L., et al., 2012. Coculture of dental pulp stem cells with endothelial cells enhances osteo-/odontogenic and angiogenic potential in vitro. J Endod. 38, 454-463.

42. Dissanayaka, W. L., et al., 2011. Characterization of dental pulp stem cells isolated from canine premolars. J Endod. 37, 1074-80.

43. Djouad, F., et al., 2010. Activin A expression regulates multipotency of mesenchymal progenitor cells. Stem Cell Res Ther. 1, 11.

44. Dolatshahi-Pirouz, A., et al., 2010. Fibronectin adsorption, cell adhesion, and proliferation on nanostructured tantalum surfaces. ACS Nano. 4, 2874-2882.

45. Duailibi, M.T., et al., 2011. Tooth tissue engineering: optimal dental stem cell harvest based on tooth development. Artif Organs. 35, 129-135.

46. Ebrahimi, B., et al., 2011. Human dental pulp stem cells express many pluripotency regulators and differentiate into neuronal cells. Neural Regeneration Research. 6, 2666-2672.

47. Egbuniwe, O., et al., 2011. P16/p53 expression and telomerase activity in immortalized human dental pulp cells. Cell Cycle. 10, 3912-3919.

48. Eleuterio, E., et al., 2013. Proteome of human stem cells from periodontal ligament and dental pulp. PLoS One. 8, 1-12.

49. Eslaminejad, M.B., et al., 2013. Odontogenic differentiation of dental pulp-derived stem cells on tricalcium phosphate scaffolds. Journal of Dental Sciences. 8, 306-313.

50. Eslaminejad, M.B., et al., 2010. Isolation and in vitro Characterization of Mesenchymal Stem Cells Derived from the Pulp Tissue of Human Third Molar Tooth Iranian Journal of Medical Sciences. 35, 216-225.

51. Eslaminejad, M.B., et al., 2010. In vitro Growth and Characterization of Stem Cells from Human Dental Pulp of Deciduous Versus Permanent Teeth. J Dent (Tehran). 7, 185-95.

52. Eslaminejad, M.R.B., et al., 2009. Human Dental Pulp Stem Cells: The Culture Optimization for Increased Growth International Journal of Hematology-Oncology and Stem Cell Research. 3, 5-13.

53. Eubanks, E.J., et al, 2014. Tooth storage, dental pulp stem cell isolation, and clinical scale expansion without animal serum. Journal of Endodontics. 40, 5, 652-657.

54. Fang, C.Z., et al., 2013. Intraventricular injection of human dental pulp stem cells improves hypoxic-ischemic brain damage in neonatal rats. PLoS One. 8, 1-7.

55. Feng, X., et al., 2014. Repeated lipopolysaccharide stimulation promotes cellular senescence in human dental pulp stem cells (DPSCs). Cell Tissue Res. 356, 2, 369-380.

56. Feng, X., et al., 2013. TNF-alpha triggers osteogenic differentiation of human dental pulp stem cells via the NF-kappaB signalling pathway. Cell Biol Int. 37, 1267-1275.

57. Feng, X., et al, 2013. Age-dependent impaired neurogenic differentiation capacity of dental stem cell is associated with Wnt/beta-catenin signaling. Cell Mol Neurobiol. 33, 10231031.

58. Foudah, D., et al., 2014. Expression of Neural Markers by Undifferentiated Mesenchymal-Like Stem Cells from
Different Sources. Journal of Immunology Research. 2014, 1-16.

59. Gabanyi, I., et al., 2013. VP22 herpes simplex virus protein can transduce proteins into stem cells. Braz J Med Biol Res. 46, 121-7.

60. Gandia, C., et al., 2008. Human dental pulp stem cells improve left ventricular function, induce angiogenesis, and reduce infarct size in rats with acute myocardial infarction. Stem Cells. 26, 638-645.

61. Gay, I., et al., 2014. Differentiation of human dental stem cells reveals a role for microRNA-218. J Periodontal Res. 49, 110-120.

62. Giorgini, E., et al., 2011. FT-IR microscopic analysis on human dental pulp stem cells. Vibrational Spectroscopy. 57, 30-34.

63. Govindasamy, V., et al., 2011. Human platelet lysate permits scale-up of dental pulp stromal cells for clinical applications. Cytotherapy. 13, 1221-1233.

64. Govindasamy, V., et al., 2010. Inherent differential propensity of dental pulp stem cells derived from human deciduous and permanent teeth. J Endod. 36, 1504-1515.

65. Govindasamy, V., et al., 2010. Micromanipulation of culture niche permits long-term expansion of dental pulp stem cells-an economic and commercial angle. In Vitro Cellular \& Developmental Biology-Animal. 46, 764-773.

66. Graziano, A., et al., 2008. Scaffold's surface geometry significantly affects human stem cell bone tissue engineering. Journal of Cellular Physiology. 214, 166-172.

67. Graziano, A., et al., 2007. Concave pit-containing scaffold surfaces improve stem cell-derived osteoblast performance and lead to significant bone tissue formation. PLoS One. 2, 1-9.

68. Gronthos, S., et al., 2000. Postnatal human dental pulp stem cells (DPSCs) in vitro and in vivo. Proc Natl Acad Sci U S A. 97, 13625-13630.

69. Han, M-J., et al., 2010. Upregulation of Bone-like Extracellular Matrix Expression in Human Dental Pulp Stem Cells by Mechanical Strain. Biotechnology and Bioprocess Engineering. $15,572-579$.

70. Han, M-J., et al., 2008. Effect of mechanical tension on the human dental pulp cells. Biotechnology and Bioprocess Engineering. 13, 410-417.

71. Havelek, R., et al., 2013. Ionizing radiation induces senescence and differentiation of human dental pulp stem cells. Folia Biol (Praha). 59, 188-197.

72. He, W., et al., 2014. Lipopolysaccharide enhances Wnt5a expression through toll-like receptor 4, myeloid differentiating factor 88, phosphatidylinositol 3-OH kinase/AKT and nuclear factor kappa B pathways in human dental pulp stem cells. J Endod. 40, 69-75.

73. He, W., et al., 2013. LPS induces IL-8 expression through TLR4, MyD88, NF-kappaB and MAPK pathways in human dental pulp stem cells. Int Endod J. 46,128-136.

74. He, H., et al., 2008. Effects of FGF2 and TGFbeta1 on the differentiation of human dental pulp stem cells in vitro. Cell Biol Int. 32, 827-834.

75. Hilkens, P., et al., 2013. Effect of isolation methodology on stem cell properties and multilineage differentiation potential of human dental pulp stem cells. Cell Tissue Res. 353, 65-78.

76. Hirata, T. M., et al., 2010. Expression of multiple stem cell markers in dental pulp cells cultured in serum-free media. J Endod. 36, 1139-1144.

77. Hoss, M., et al., 2013. Integrin alpha4 impacts on differential adhesion of preadipocytes and stem cells on synthetic polymers. J Tissue Eng Regen Med. 7, 312-323. 
78. Huang, C.H., et al., 2010. Glucosamine promotes osteogenic differentiation of dental pulp stem cells through modulating the level of the transforming growth factor-beta type I receptor. J Cell Physiol. 225, 140-51.

79. Huang, G.T., et al., 2010. Stem/progenitor cell-mediated de novo regeneration of dental pulp with newly deposited continuous layer of dentin in an in vivo model. Tissue Eng Part A.16, 605-615.

80. Huang, A.H., et al.,2009. Chen YK, Chan AW, Shieh TY, Lin LM. Isolation and characterization of human dental pulp stem/stromal cells from nonextracted crown-fractured teeth requiring root canal therapy. J Endod. 35, 673-681.

81. Huang, A.H., et al., 2008. Isolation and characterization of dental pulp stem cells from a supernumerary tooth. J Oral Pathol Med. 37, 571-574.

82. Ishkitiev, N., et al., 2012. High-purity hepatic lineage differentiated from dental pulp stem cells in serum-free medium. J Endod. 38, 475-480.

83. Ishkitiev, N., et al., 2010. Deciduous and Permanent Dental Pulp Mesenchymal Cells Acquire Hepatic Morphologic and Functional Features In Vitro. Journal of Endodontics. 36, 469-474.

84. Jeon, B.G., et al., 2011. Comparative analysis of telomere length, telomerase and reverse transcriptase activity in human dental stem cells. Cell Transplant. 20, 1693-1705.

85. Jin, H., et al., 2013. HDAC inhibitor trichostatin A promotes proliferation and odontoblast differentiation of human dental pulp stem cells. Tissue Eng Part A. 19, 613-24.

86. Kadar, K., et al., 2009. Differentiation potential of stem cells from human dental origin - promise for tissue engineering. J Physiol Pharmacol. 60, 167-75.

87. Kanafi, M., et al., 2014. Midbrain Cues Dictate Differentiation of Human Dental Pulp Stem Cells Towards Functional Dopaminergic Neurons. J Cell Physiol. 229, 1369-1377

88. Kanafi, M.M., et al., 2013. Phenotypic and functional comparison of optimum culture conditions for upscaling of dental pulp stem cells. Cell Biol Int. 37, 126-136.

89. Kanafi, M.M., et al., 2013 Transplantation of islet-like cell clusters derived from human dental pulp stem cells restores normoglycemia in diabetic mice. Cytotherapy. 15, 1228-1236.

90. Kanafi, M.M., et al., 2013 .Influence of hypoxia, high glucose, and low serum on the growth kinetics of mesenchymal stem cells from deciduous and permanent teeth. Cells, tissues, organs. 198,198-208.

91. Kanafi, M.M., et al., 2013. Dental pulp stem cells immobilized in alginate microspheres for applications in bone tissue engineering. Int Endod J. 47, 687-697.

92. Karaoz, E., et al., 2011. Human dental pulp stem cells demonstrate better neural and epithelial stem cell properties than bone marrow-derived mesenchymal stem cells. Histochem Cell Biol. 136, 455-473.

93. Karbanova, J., et al., 2011. Characterization of dental pulp stem cells from impacted third molars cultured in low serumcontaining medium. Cells, tissues, organs. 193, 344-365.

94. Karbanova, J., et al., 2010. Osteogenic differentiation of human dental pulp-derived stem cells under various ex-vivo culture conditions. Acta Medica (Hradec Kralove). 53, 79-84.

95. Kawanabe, N., et al., 2012. Stage-specific embryonic antigen-4 identifies human dental pulp stem cells. Exp Cell Res. 318, 453-463.

96. Kellner, M., et al., 2014. Differences of isolated dental stem cells dependent on donor age and consequences for autologous tooth replacement. Arch Oral Biol. 59, 559-567.
97. Khanna-Jain, R., et al., 2012. Osteogenic differentiation of human dental pulp stem cells on beta-tricalcium phosphate/ poly (l-lactic acid/caprolactone) three-dimensional scaffolds. J Tissue Eng. 3, 1-11.

98. Kim, J.H., et al., 2013. The role of lysyl oxidase-like 2 in the odontogenic differentiation of human dental pulp stem cells. Mol Cells. 35, 543-549.

99. Kim, S.H., et al., 2011. Gene expression profile in mesenchymal stem cells derived from dental tissues and bone marrow. J Periodontal Implant Sci. 41, 192-200.

100.Kiraly, M., et al., 2011. Integration of neuronally predifferentiated human dental pulp stem cells into rat brain in vivo. Neurochem Int. 59, 371-381.

101. Kiraly, M., et al., 2009. Simultaneous PKC and cAMP activation induces differentiation of human dental pulp stem cells into functionally active neurons. Neurochem Int. 55, 323-332.

102. Kolind, K., et al., 2014. Control of proliferation and osteogenic differentiation of human dental-pulp-derived stem cells by distinct surface structures. Acta Biomater. 10, 641-650.

103. Koyama, N., et al., 2009. Evaluation of pluripotency in human dental pulp cells. J Oral Maxillofac Surg. 67, 501-506.

104. Kraft, D.C., et al., 2010. Mechanosensitivity of dental pulp stem cells is related to their osteogenic maturity. Eur J Oral Sci. 118, 29-38.

105. Laino, G., et al., 2006. In vitro bone production using stem cells derived from human dental pulp. J Craniofac Surg. 17, 511-515.

106. Laino, G., et al., 2005. A new population of human adult dental pulp stem cells: a useful source of living autologous fibrous bone tissue (LAB). J Bone Miner Res. 20, 1394-1402.

107. Lee, C.H., et al., 2014. Three-dimensional printed multiphase scaffolds for regeneration of periodontium complex. Tissue Eng Part A. 20, 1342-1351.

108. Lee, S.Y., et al., 2012. Magnetic cryopreservation for dental pulp stem cells. Cells, tissues, organs. 196, 23-33.

109. Lee, E.H., et al., 2011. The role of asporin in mineralization of human dental pulp stem cells. J Cell Physiol. 226, 1676-1682.

110. Lee, J.H., et al., 2011. Odontogenic differentiation of human dental pulp stem cells induced by preameloblast-derived factors. Biomaterials. 32, 9696-9706.

111. Lee, J.Y., et al., 2011. The effects of platelet-rich plasma derived from human umbilical cord blood on the osteogenic differentiation of human dental stem cells. In Vitro Cell Dev Biol Anim. 47, 157-164.

112. Lee, U.L., et al., 2011. Effect of platelet-rich plasma on dental stem cells derived from human impacted third molars. Regen Med. 6, 67-79.

113. Lee, S.H., et al., 2010. Comparison of ganglioside expression between human adipose- and dental pulp-derived stem cell differentiation into osteoblasts. Arch Pharm Res. 33, 585-591.

114. Lee, S.H., et al., 2010. Culture of Mesenchymal Stromal Cells from Dental Pulp: Culture Medium Study for Effective Expansion and Characterization. Tissue Engineering and Regenerative Medicine. 7, 248-254.

115. Lee, S.Y., et al., 2010. Effects of cryopreservation of intact teeth on the isolated dental pulp stem cells. J Endod. 36, 1336-1340.

116. Lee, E., et al., 2008. Distinct Expression Profiles in Type III Collagen and alpha-Smooth Muscle Actin between Human Dental Pulp Stem Cells and Human Mesenchymal Stem Cells. Tissue Engineering and Regenerative Medicine. 5, 559-564. 
117. Li, J.H., et al., 2011. Human dental pulp stem cell is a promising autologous seed cell for bone tissue engineering. Chin Med J (Engl). 124, 4022-4028.

118. Lin, C.Y., et al., 2011. Zinc chloride for odontogenesis of dental pulp stem cells via metallothionein up-regulation. J Endod. 37, 211-216.

119. Lindroos, B., et al., 2008. Characterisation of human dental stem cells and buccal mucosa fibroblasts. Biochemical and Biophysical Research Communications. 368, 329-335.

120. Liu, H., et al., 2004. Dentonin, a fragment of MEPE, enhanced dental pulp stem cell proliferation. J Dent Res. 83, 496-499.

121. Luo, Z., et al., 2014. Biodentine induces human dental pulp stem cell differentiation through mitogen-activated protein kinase and calcium-/calmodulin-dependent protein kinase II pathways. Journal of Endodontics. 40, 937-942

122. Luo, Z., et al., 2014. Effect of Biodentine on the proliferation, migration and adhesion of human dental pulp stem cells. J Dent. 42, 490-497.

123. Ma, D., et al., 2012. Changes in proliferation and osteogenic differentiation of stem cells from deep caries in vitro. J Endod. 38, 796-802.

124. Makino, Y., et al., 2013. Immune therapeutic potential of stem cells from human supernumerary teeth. J Dent Res. 92, 609-615.

125. Mangano, C., et al., 2011. Human dental pulp stem cells hook into biocoral scaffold forming an engineered biocomplex. PLoS One. 6, 1-9.

126. Mangano, C., et al., 2010. The osteoblastic differentiation of dental pulp stem cells and bone formation on different titanium surface textures. Biomaterials. 31, 3543-3551.

127. Manikandhan, R., et al., 2010. Successful isolation, in vitro expansion and characterization of stem cells from Human Dental Pulp. J Stem Cells Regen Med. 6, 168-169.

128. Marchionni, C., et al., 2009. Angiogenic potential of human dental pulp stromal (stem) cells. Int J Immunopathol Pharmacol. 22, 699-706.

129. Martens, W., et al., 2012. Expression pattern of basal markers in human dental pulp stem cells and tissue. Cells, tissues, organs. 196, 490-500.

130. Martin-Piedra, M.A., et al., 2013. Average cell viability levels of human dental pulp stem cells: an accurate combinatorial index for quality control in tissue engineering. Cytotherapy. 15, 507-518.

131. Min, J. H., et al., 2011. Dentinogenic potential of human adult dental pulp cells during the extended primary culture. Hum Cell. 24, 43-50.

132. Mokry, J., et al. 2010. Telomere attrition occurs during ex vivo expansion of human dental pulp stem cells. J Biomed Biotechnol. 2010, 1-11.

133. Mori, G., et al., 2011. Dental pulp stem cells: osteogenic differentiation and gene expression. Ann N Y Acad Sci. 1237, 47-52.

134. Murakami, M., et al., 2013. The use of granulocyte-colony stimulating factor induced mobilization for isolation of dental pulp stem cells with high regenerative potential. Biomaterials. 34, 9036-9047.

135. Murakami, M., et al., 2012. Identification of novel function of vimentin for quality standard for regenerated pulp tissue. J Endod. 38, 920-926.

136. Muthna, D., et al., 2010. Irradiation of adult human dental pulp stem cells provokes activation of p53, cell cycle arrest, and senescence but not apoptosis. Stem Cells Dev. 19, 1855-1862.

137. Nadeem, D., et al., 2013. Fabrication and in vitro evaluation of a sponge-like bioactive-glass/gelatin composite scaffold for bone tissue engineering. Mater Sci Eng C Mater Biol Appl. 33, 2669-2678.
138. Nakamura, S., et al., 2009. Stem cell proliferation pathways comparison between human exfoliated deciduous teeth and dental pulp stem cells by gene expression profile from promising dental pulp. J Endod. 35, 1536-1542.

139. Nam, S., et al., 2011. Odontogenic differentiation of human dental pulp stem cells stimulated by the calcium phosphate porous granules. J Tissue Eng. 2011, 1-10.

140. Navabazam, A.R., et al., 2013. Characterization of mesenchymal stem cells from human dental pulp, preapical follicle and periodontal ligament. Iranian Journal of Reproductive Medicine. 11, 235-242.

141. Mat Nawi NSB, Ariffin Z, Alam MK, Mohd Noor SNF, Hassan A. International Medical Journal. 2013;20:593-6.

142. Nesti, C., et al., 2011. Human dental pulp stem cells protect mouse dopaminergic neurons against MPP+ or rotenone. Brain Res. 1367, 94-102.

143. Neuss, S., et al., 2008. Assessment of stem cell/biomaterial combinations for stem cell-based tissue engineering. Biomaterials. 29, 302-313.

144. Niu, L.N., et al., 2014. Intrafibrillar-silicified collagen scaffolds enhance the osteogenic capacity of human dental pulp stem cells. J Dent. 42, 839-849.

145. Oancea, R., et al., 2013. Behavioural Changes and Plastic Potential Alteration of Dental Pulp Stem Cells Exposed to High Glucose Concentrations. Digest Journal of Nanomaterials and Biostructures. 8, 313-321.

146. Okamoto, Y., et al., 2009. Simvastatin induces the odontogenic differentiation of human dental pulp stem cells in vitro and in vivo. J Endod. 35, 367-372.

147. Osathanon, T., et al., 2014. Neurogenic differentiation of human dental pulp stem cells using different induction protocols. Oral Dis. 20, 352-358.

148. Osathanon, T., Nowwarote, N., Pavasant, P., 2011. Basic fibroblast growth factor inhibits mineralization but induces neuronal differentiation by human dental pulp stem cells through a FGFR and PLCgamma signaling pathway. J Cell Biochem. 112, 1807-1816.

149. Paino, F., et al., 2010. Ecto-mesenchymal stem cells from dental pulp are committed to differentiate into active melanocytes. Eur Cell Mater. 20, 295-305.

150. Palumbo, C., et al., 2013. Immunocytochemical and structural comparative study of committed versus multipotent stem cells cultured with different biomaterials. Micron. 47, 1-9.

151. Pang, N.S., et al., 2014. Effect of EDTA on attachment and differentiation of dental pulp stem cells. J of Endodontics. 40, 811-817.

152. Papaccio, G., et al. 2006. Long-term cryopreservation of dental pulp stem cells (SBP-DPSCs) and their differentiated osteoblasts: a cell source for tissue repair. J Cell Physiol. 208, 319-325.

153. Park, J-Y., et al., 2013. Comparative analysis of mesenchymal stem cell surface marker expression for human dental mesenchymal stem cells. Regenerative Medicine. 8, 453-466.

154. Patil, R., et al., 2014. Multilineage potential and proteomic profiling of human dental stem cells derived from a single donor. Exp Cell Res. 320, 92-107.

155. Pereira, L.O., Figueiro, L.J.P., Azevedo, R.B., 2012. Laser irradiation did not increase the proliferation or the differentiation of stem cells from normal and inflamed dental pulp. Archives of Oral Biology. 57, 1079-1085.

156. Pereira, L.O., et al. 2012. Comparison of stem cell properties of cells isolated from normal and inflamed dental pulps. Int Endod J. 45, 1080-1090. 
157. Perry, B.C., et al., 2008. Collection, cryopreservation, and characterization of human dental pulp-derived mesenchymal stem cells for banking and clinical use. Tissue Eng Part C Methods. 14, 149-156.

158. Picchi, J., et al., 2013. HOX and TALE signatures specify human stromal stem cell populations from different sources. J Cell Physiol. 228, 879-889.

159. Pierdomenico, L., et al., 2005. Multipotent mesenchymal stem cells with immunosuppressive activity can be easily isolated from dental pulp. Transplantation. 80, 836-842.

160. Ponnaiyan, D., Bhat, K.M., Bhat, G.S., 2012. Comparison of immuno-phenotypes of stem cells from human dental pulp and periodontal ligament. Int J Immunopathol Pharmacol. 25, 127-134.

161. Riccio, M., et al., 2013. Human dental pulp stem cells produce mineralized matrix in 2D and 3D cultures. Eur J Histochem. 54, 213-221.

162. Rizk, A., Rabie, A.B., 2013. Human dental pulp stem cells expressing transforming growth factor beta 3 transgene for cartilage-like tissue engineering. Cytotherapy. 15, 712-725.

163. Rizk, A., Rabie, B.M., 2013. Electroporation for transfection and differentiation of dental pulp stem cells. Biores Open Access. 2, 155-162.

164. Rodriguez-Lozano, F.J., et al., 2013. Effects of two low-shrinkage composites on dental stem cells (viability, cell damaged or apoptosis and mesenchymal markers expression). J Mater Sci Mater Med. 24, 979-988.

165. Rodriguez-Lozano, F.J., et al., 2012. Tissue engineering with dental pulp stem cells: isolation, characterization, and osteogenic differentiation. J Craniofac Surg. 23, 571-575.

166. Ryu, J.S., et al., 2009. Gangliosides are involved in neural differentiation of human dental pulp-derived stem cells. Biochem Biophys Res Commun. 387, 266-271.

167. Sakai, K., et al., 2012. Human dental pulp-derived stem cells promote locomotor recovery after complete transection of the rat spinal cord by multiple neuro-regenerative mechanisms. J Clin Invest. 122, 80-90.

168. Schiraldi, C., et al., 2012. Fighting for territories: time-lapse analysis of dental pulp and dental follicle stem cells in coculture reveals specific migratory capabilities. Eur Cell Mater. $24,426-440$.

169. Seifrtova, M., et al., 2013. Mitoxantrone ability to induce premature senescence in human dental pulp stem cells and human dermal fibroblasts. J Physiol Pharmacol. 64, 255-266.

170. Seifrtova, M., et al., 2012. The response of human ectomesenchymal dental pulp stem cells to cisplatin treatment. Int Endod J. 45, 401-412.

171. Seo, M.S., et al., 2013. The effect of mineral trioxide aggregate on odontogenic differentiation in dental pulp stem cells. J Endod. 39, 242-248.

172. Shafiei, F., et al., 2014. Cytotoxic effect of silorane and methacrylate based composites on the human dental pulp stem cells and fibroblasts. Med Oral Patol Oral Cir Bucal. $19,350-358$

173. Shekar, R., Ranganathan, K., 2012. Phenotypic and growth characterization of human mesenchymal stem cells cultured from permanent and deciduous teeth. Indian J Dent Res. 23, 838-839.

174. Shi, S., Bianco, P., Robey, P.G., Gronthos, S., 2003. Perivascular niche of postnatal mesenchymal stem cells in human bone marrow and dental pulp. Journal of Bone and Mineral Research. 18, 696-704.
175. Sollazzo, V., et al., 2011. Calcium sulfate stimulates pulp stem cells towards osteoblasts differentiation. Int J Immunopathol Pharmacol. 24, 51-57.

176. Son, Y., Lee, E., 2006. Distinct Expression Profiles in Type III Collagen and alpha-Smooth Muscle Actin between Human Dental Pulp Stem Cells and Human Mesenchymal Stem Cells. Molecular Biology of the Cell. 17.

177. Spath, L., et al., 2010. Explant-derived human dental pulp stem cells enhance differentiation and proliferation potentials. J Cell Mol Med. 14, 1635-1644.

178. Stevens, A., et al., 2008. Human dental pulp stem cells differentiate into neural crest-derived melanocytes and have label-retaining and sphere-forming abilities. Stem Cells Dev. $17,1175-1184$

179. Stokowski, A., et al., 2007. EphB/ephrin-B interaction mediates adult stem cell attachment, spreading, and migration: implications for dental tissue repair. Stem Cells. $25,156-164$.

180. Struys, T., et al., 2013. Magnetic resonance imaging of human dental pulp stem cells in vitro and in vivo. Cell Transplant. 22, 1813-1829.

181. Struys, T., etal., 2011. Ultrastructural and immunocytochemical analysis of multilineage differentiated human dental pulpand umbilical cord-derived mesenchymal stem cells. Cells, tissues, organs. 193, 366-378.

182. Suchanek, J., et al., 2013. The effect of fetal calf serum on human dental pulp stem cells. Acta Medica (Hradec Kralove). 56, 142-149.

183. Suchanek, J., et al., 2009. Dental pulp stem cells and their characterization. Biomed Pap Med Fac Univ Palacky Olomouc Czech Repub. 153, 31-35.

184. Suchanek, J., et al., 2007. Human dental pulp stem cells-isolation and long term cultivation. Acta Medica (Hradec Kralove). 50, 195-201.

185. Suh, J-D., et al., 2014. Effects of Co-Culture of Dental Pulp Stem Cells and Periodontal Ligament Stem Cells on Assembled Dual Disc Scaffolds. Tissue Engineering and Regenerative Medicine. 11, 47-58.

186. Suri, L., et al., 2008. Expression of MMP-13 (collagenase-3) in long-term cultures of human dental pulp cells. Archives of Oral Biology. 53, 791-799.

187. Suzuki, T., et al., 2011. Induced migration of dental pulp stem cells for in vivo pulp regeneration. J Dent Res. 90, 1013-1018.

188. Tamaki, Y., et al., 2013. In vitro analysis of mesenchymal stem cells derived from human teeth and bone marrow. Odontology. 101, 121-132.

189. Tammaro, L., et al., 2014. Effect of layered double hydroxide intercalated with fluoride ions on the physical, biological and release properties of a dental composite resin. J Dent. 42, 60-67.

190. Tandon, S., et al., 2010. Dental pulp stem cells from primary and permanent teeth: quality analysis. J Clin Pediatr Dent. 35, 53-58.

191. Tirino, V., et al., 2012. Identification, isolation, characterization, and banking of human dental pulp stem cells. Methods Mol Biol. 879, 443-463.

192. Tomic, S., et al., 2011. Immunomodulatory properties of mesenchymal stem cells derived from dental pulp and dental follicle are susceptible to activation by toll-like receptor agonists. Stem Cells Dev. 20, 695-708.

193. Tom-Kun Yamagishi, V., et al., 2011. Blockade of TLR2 inhibits Porphyromonas gingivalis suppression of mineralized 
matrix formation by human dental pulp stem cells.Journal of Endodontics. 37, 812-818.

194. Trubiani, O., et al., 2012. Overexpression of interleukin-6 and -8 , cell growth inhibition and morphological changes in 2-hydroxyethyl methacrylate-treated human dental pulp mesenchymal stem cells. Int Endod J. 45, 19-25.

195. Trubiani, O., et al., 2010. The cytotoxic effects of resin-based sealers on dental pulp stem cells. International Endodontic Journal. 43, 646-653.

196. Trubiani, O., et al., 2007. Dental pulp stem cells bioadhesivity: evaluation on mineral-trioxide-aggregate. Int J Immunopathol Pharmacol. 20, 81-86.

197. Uchiyama, M., et al., 2009. Dental Pulp and Periodontal Ligament Cells Support Osteoclastic differentiation. Journal of Dental Research. 88, 609-614.

198. Um, S., et al., 2011. Effect of leptin on differentiation of human dental stem cells. Oral Dis. 17, 662-669.

199. Vandomme, J., et al., 2014. Insulin-Like Growth Factor 1 Receptor and p38 Mitogen-Activated Protein Kinase Signals Inversely Regulate Signal Transducer and Activator of Transcription 3 Activity to Control Human Dental Pulp Stem Cell Quiescence, Propagation, and Differentiation. Stem Cells Dev. 23, 839-851.

200. Varga, I., et al., 2011. Morphological characterization of in vitro expanded human dental pulp-derived stem cells. Biologia. 66, 706-711.

201. Vasandan, A.B., et al., 2014. Functional differences in mesenchymal stromal cells from human dental pulp and periodontal ligament. Journal of Cellular and Molecular Medicine. 18, 344-354.

202. Ventura, C., et al., 2007. Hyaluronan mixed esters of butyric and retinoic Acid drive cardiac and endothelial fate in term placenta human mesenchymal stem cells and enhance cardiac repair in infarcted rat hearts. J Biol Chem. 282, 14243-14252.

203. Vishwanath, V.R., et al., 2013. Differentiation of isolated and characterized human dental pulp stem cells and stem cells from human exfoliated deciduous teeth: An in vitro study. J Conserv Dent. 16, 423-428.

204. Wada, N., et al., 2009. Immunomodulatory properties of human periodontal ligament stem cells. J Cell Physiol. 219, 667-676.

205. Wang, P., et al., 2014. Ginsenoside Rg1 of Panax ginseng stimulates the proliferation, odontogenic/osteogenic differentiation and gene expression profiles of human dental pulp stem cells. Phytomedicine. 21,177-183.

206. Wang, Y., et al., 2013. Osteoblasts can induce dental pulp stem cells to undergo osteogenic differentiation. Cytotechnology. $65,223-231$.

207. Wang, Y., et al., 2013. 10(-7) m 17beta-oestradiol enhances odonto/osteogenic potency of human dental pulp stem cells by activation of the NF-kappaB pathway. Cell Prolif. 46, 677-684.

208. Wang, X., et al., 2012. Comparative characterization of stem cells from human exfoliated deciduous teeth and dental pulp stem cells. Arch Oral Biol. 57, 1231-1240.

209. Wang, J., et al., 2010. Side population increase after simulated transient ischemia in human dental pulp cell. J Endod. 36, 453-458.

210. Weszl, M., et al., 2012. Freeze-dried human serum albumin improves the adherence and proliferation of mesenchymal stem cells on mineralized human bone allografts. Journal of Orthopaedic Research. 30, 489-496.

211. Woods, E.J., et al., 2009. Optimized cryopreservation method for human dental pulp-derived stem cells and their tissues of origin for banking and clinical use. Cryobiology. 59, 150-157.

212. Yan, X., et al., 2010. iPS cells reprogrammed from human mesenchymal-like stem/progenitor cells of dental tissue origin. Stem Cells Dev. 19, 469-480.

213. Yu, V., et al., 2009. Dynamic hydrostatic pressure promotes differentiation of human dental pulp stem cells. Biochem Biophys Res Commun. 386, 661-665.

214. Zhai, S., et al., 2013. Nemotic human dental pulp fibroblasts promote human dental pulp stem cells migration. Exp Cell Res. 319, 1544-1552.

215. Zhang, W., et al., 2011. Human dental pulp progenitor cell behavior on aqueous and hexafluoroisopropanol based silk scaffolds. J Biomed Mater Res A. 97, 414-422.

216. Zhang, W., Ahluwalia, I.P., Yelick, P.C., 2010. Three dimensional dental epithelial-mesenchymal constructs of predetermined size and shape for tooth regeneration. Biomaterials. 31, 7995-8003.

217. Zhang, W., et al., 2008. Hard tissue formation in a porous HA/TCP ceramic scaffold loaded with stromal cells derived from dental pulp and bone marrow. Tissue Eng Part A. 14, 285-294.

218. Zhang, W., et al., 2008. In vivo evaluation of human dental pulp stem cells differentiated towards multiple lineages. J Tissue Eng Regen Med. 2, 117-125.

219. Zhang, W., 2006. Multilineage differentiation potential of stem cells derived from human dental pulp after cryopreservation. Tissue Eng. 12, 2813-2823.

220. Zhao, Z., Liu, H., Wang, D., 2011. ADAM28 manipulates proliferation, differentiation, and apoptosis of human dental pulp stem cells. J Endod. 37, 332-339.

221. Zhao, Z., et al., 2006. ADAM28 participates in the regulation of tooth development. Arch Oral Biol. 51, 996-1005.

222. Zhou, Y., Fan, W., Xiao, Y., 2014. The Effect of Hypoxia on the Stemness and Differentiation Capacity of PDLC and DPC. Biomed Res Int. 2014, 1-7. 